\title{
Öğretmen Adaylarının Öğretim Teknolojileri ve Materyal Tasarımı Dersine ilişkin Görüşleri
}

\author{
Doç. Dr. Ebru Bozpolat \\ Cumhuriyet Üniversitesi-Türkiye \\ ebozpolat@gmail.com
}

\author{
Aysel Arslan (Öğr. Gör.) \\ Cumhuriyet Üniversitesi-Türkiye \\ arslanaysel.58@gmail.com
}

\section{Özet:}

Bu çalışmanın amacı, öğretmen adaylarının Öğretim Teknolojileri ve Materyal Tasarımı (ÖTMT) dersine ilişkin görüşlerini belirlemektir. Nitel araştırma yönteminin kullanıldığı bu araştırmada, bir durumun derinlemesine çalışmasına imkân sağlayan durum çalışması deseni kullanılmıştır. Araştırma, 2016-2017 eğitim-öğretim yılı bahar döneminde Cumhuriyet Üniversitesi Eğitim Fakültesi'nde eğitim görmekte olan 50 öğrenci ile gerçekleştirilmiştir. Araştırmada, veri toplama aracı olarak, 7 açık uçlu sorudan oluşan yarı yapılandırılmış görüşme formu kullanılmıştır. Öğrencilere öğretim materyallerinin taşıması gereken özellikler, ögretim materyali hazırlanırken dikkat edilmesi gereken özellikler, materyal hazırlamanın katkıları, materyal hazırlamada karşılaşılan problem durumları, materyal hazırlayan öğrencilerin taşıması gereken özellikler, ÖTMT dersinin katkıları ve okullardaki materyal kullanımı ile ilgili sorular yöneltilmiştir. Verilerin çözümlenmesinde, içerik analizi yöntemi kullanılmıştır. Elde edilen bulgulara göre ögretmen adayları ögretim materyallerinin hedeflere uygun olması, ögrencinin seviyesine uygun olması, kullanışlı olması gerektiğini ifade etmişlerdir. Hazırlanan materyallerin öğrenmeyi kolaylaştırdığı, kalıclığını sağladığı, bütün okullarda kullanılması gerektiği de ulaşılan diğer bulgular arasında yer almaktadır.

Anahtar Kelimeler: Öğretim teknolojileri, materyal tasarımı, öğretmen adayı.

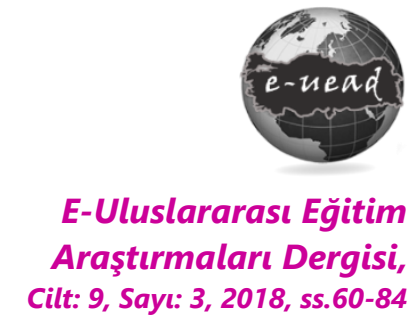

DOI: 10.19160/ijer.463977

\section{Önerilen Atıf}

Bozpolat, E. \&. Arslan, A. (2018). Öğretmen Adaylarının Öğretim Teknolojileri ve Materyal Tasarımı Dersine Illişkin Görüşleri, E-Uluslararası Eğitim Araştırmaları Dergisi, Cilt: 9, Sayı: 3, 2018, ss. 60-84, DOI: 10.19160/ijer.463977 


\section{Giriş}

Günümüz dünyasında, temelinde bilim ve teknoloji alanındaki ilerlemelerin yattığı hızlı bir değişim ve gelişim yaşanmaktadır. Bilim ve teknoloji temelli değişim ve gelişim süreci toplumların hayatında bilginin gücünü öne çıkarmakta (Sönmez, 2006) ve bu güç çağımızın en etkili silahlarından biri olarak kabul edilmektedir. Artık eğitim; ülkeler arasında stratejik olarak gitgide daha fazla değer kazanırken, bireylerin de eğitim-öğretim sürecinde gerekli bilgi ve donanımı kazanmış bireyler olarak yetişmeleri gerekmektedir (Sönmez, 2006; Geçer, 2010). Bu açıdan bakıldığında; aktif, çok yönlü ve eleştirel düşünen, sorunlara çözüm üreten, kendini günün intiyaçlarına göre sürekli geliştiren (Birişçi ve Karal, 2011), sadece çevresindeki değil dünyadaki değişimleri takip eden, teknolojiden etkin olarak yararlanan ve dünya vatandaşlığı kimliğini taşıyan bireylerin yetiştirilmesi önemli görülmektedir (Güven, 2006). Toplumlar bu niteliklere sahip bireyleri ancak eğitim yoluyla yetiştirebilmektedir.

Eğitim sürecinde, hem öğretmenlerin hem de öğrencilerin gereksinim duydukları bilgileri arayıp bulmasının (Köseoğlu ve Soran, 2006) yanı sıra bilgiyi kullanma konusunda kendilerini yetiştirmelerinin gerekliliği kabul edilmektedir (Sönmez, 2006). Bireylerin bunu gerçekleştirebilmeleri için de eğitim programlarında öğrenci merkezli, bireyi etkin kılan, onlara seçenek sunan eğitim yaklaşımları benimsenmektedir. Bu yaklaşımlardan biri olan yapılandırmacı eğitim anlayışı, bireylerin önceki yaşantılarına ait bilgi ve deneyimlerini kullanarak yeni bilgileri oluşturması temeline dayanmaktadır (Şaşmaz Ören ve Ormancı, 2012). Yapılandırmacı yaklaşımın önemli özelliklerinin başında eğitim sürecinde öğrencinin aktif, öğretmenin ise rehber rolünde olması gelmektedir (Demiralp, 2007). Yapılandırmacı eğitim yaklaşımında; öğrenci merkezli pek çok farklı yöntem, teknik, strateji kullanılması; öğrenciyi aktif kılan materyaller geliştirilerek etkili öğrenme ortamlarının oluşturulması (Şaşmaz Ören ve Ormancı, 2012); eğitim ortamlarının yapılandırmacı yaklaşıma uygun şekilde düzenlenmesi gerekmektedir (Semerci, 2006). Yani eğitim ortamlarında istenilen sonuçların elde edilebilmesi için; öğrencilerin yaratıcı düşüncelerini ön plana çıkaran yöntem ve tekniklerin kullanılması, farklı etkinliklere yer verilmesi (Yontar, 1993; Yenilmez ve Yolcu, 2007), eğitim programlarına uygun olarak hazırlanmış ders araç-gereçlerinin kullanılması (Nalçacı ve Ercoşkun, 2005) ve öğretim teknolojilerine uygun şekilde hazırlanan öğretim materyallerinden yararlanılması zorunluluk arz etmektedir (Şahin ve Yıldırım, 1999; Çelik, 2009). Öğrenci merkezli yapılandırmacı eğitim anlayışının gereği olarak eğitimciler eğitim-öğretim sürecinde etkililiği arttırmak için sınıflarında öğretim materyallerini daha fazla ve daha etkin olarak kullanmakta (Fidan, 2008; Demiralp, 2007); böylece öğretim materyalleri öğrenme-öğretme sürecindeki temel ögelerden biri olarak yerini almaktadır (Paykoç, 1991).

Eğitimde kullanılan araç-gereç ve materyallerle ilgili olarak birçok tanımlama yapılmaktadır. Alkan (1979) araçları öğrencinin öğrenme-öğretme sürecinde öğretmene yardımcı olması için özel olarak hazırlanan öğretme-öğrenme malzemeleri olarak tanımlarken, Binbaşıŏlu (1988) herhangi bir işin yapılamasını veya anlaşımasını kolaylaştırmak amacıyla kullanılan ve süreklilik gösteren nesneler olarak tanımlamıştır. Gereçlerin ise daha çok yazılı ve basılı malzemeleri ifade ettiği belirtilmektedir (Demirel, 2011). Büyükkaragöz (1996) gereçlerin ders yapılırken kullanılan ancak bir kez kullanıldıktan sonra özelliğini kaybeden yani süreklilik göstermeyen nesneler olduğunu ifade etmektedir. Bu anlamda tahta bir araçken tebeşirin ise bir gereç olduğunu belirtmektedir. Materyal ise Türk Dil Kurumu Türkçe Sözlük'te (TDK, 2005, s. 571) "Bir şey yapmak için kullanılması gereken maddeler, malzeme" şeklinde tanımlanmıştır. Ancak bu ifade genel bir materyal tanımı olup öğretimde kullanılan materyalleri tam olarak ifade etmemektedir. Paykoç (1991) öğretim materyallerinin, öğretim sürecinde öğrencilere bilgi, beceri, tutum ve değerlerin kazandırılması amacıyla kullanılan tüm araç-gereçler ve kaynakları kapsadığını belirtmektedir. Öğretimde kullanılan materyaller denilince ilk akla gelen şey genelde kitaplar olmasına rağmen, bu oldukça eksik ve hatalı bulunmaktadır. Öğretmenlerin derslerde kullanabilecekleri materyalleri, günümüz intiyaçlarını ve imkânlarını da göz önüne alarak daha geniş bir yelpazeden seçmeleri gerektiği 
ifade edilmektedir (Ellis, 1997; Demiralp, 2007). Bu anlamda öğretmenlerin yazılı-basılı materyallerin yanı sıra daha çok duyu organına hitap eden görsel ve işitsel materyalleri kullanmalarının önemi vurgulanmaktadır (Fidan, 2008; Köseoğlu ve Soran, 2006; Sönmez, 2006).

Allwright (1981) eğitim sürecinde öğretim materyallerinin kullanılmasının en önemli sebebinin öğretmenin öğretme sürecinde eksik kaldığı yönlerinin tamamlanması olduğunu söylemektedir. Eğitim ortamlarında kullanılan materyaller öğrencilerin derse etkin katılımlarını sağlamakta, ilgilerini çekmekte ve işbirlikli çalışmalarına yardımcı olmaktadır (Köseoğlu ve Soran, 2006; Sağlam, 2010). Materyaller öğrencilerin ders sırasındaki motivasyonlarını yükseltmekte (Demiralp, 2007), onlara öğrendikleri bilgilere yönelik uygulama yapma şansı vererek (Çekirdekçi ve Toptaş, 2011; Alım ve Girgin, 2004) teoride karmaşık olan bir bilgiyi kolayca edinmelerini sağlamakta (Demiralp, 2007) ve onların yaparak yaşayarak öğrenmelerine zemin oluşturmaktadır. Günümüzde öğrenciler her alanda sürekli olarak görsel uyarıcılara maruz kalmakta ve bu durum algılarının görsel uyaranlara karşı daha açık olmasına neden olmaktadır (Borich, 2014). Eğitimde kullanılan materyallerin görsel, işitsel ve devinişsel olarak onları harekete geçirici özellikte olması, bu durumu avantaja çevirerek öğrencilerin bilgiyi daha kalıcı olarak öğrenmelerini sağlamaktadır. Özellikle çoklu öğrenme-öğretme ortamlarının oluşmasında önemli bir işlevi olan öğretim materyallerinin kullanılması, öğrencilerin öğrendikleri bilgiyi zihinlerinde yeniden yapılandırarak kalıcı hale getirmelerinde oldukça önemlidir (Şaşmaz Ören ve Ormancı, 2012; Çekirdekçi ve Toptaş, 2011; Borich, 2014; Tekdal, 2004). Öğrenilen bilgilerin somutlaştırılarak kalııı hale getirilmesinde öğretim materyallerinin oldukça büyük önem taşıdığı gerçeğinden hareketle (Semerci, 2006; Şaşmaz Ören ve Ormancı, 2012; Fidan, 2008; Demiralp, 2007; Alım ve Girgin, 2004); öğretmenlerin ve öğrencilerin ihtiyaç duydukları materyallerin sürekli olarak araştırılması ve geliştirilmesi gerekmektedir (Sönmez, 2006). Öğretim materyalleri tasarlanırken; öğrencilerin bireysel farklııklarının, ihtiyaçlarının (McLoughlin, 1999) ve hazırbulunuşluk düzeylerinin dikkate alınması (Sönmez, 2005), materyallerin öğrencilerin seviyelerine ve özelliklerine uygun olması, kolaylıkla elde edilerek kullanılabilmesi (Senemoğlu, 2007), konuya ve amaca uygun olarak seçilmesi dikkat edilmesi gereken konulardandır (Demiralp, 2007). Eğitimde doğru materyal kullanımı; öncelikle etkili bir eğitim ortamı hazırlanmasını ve öğrencilerin belirlenen hedeflere daha kolay ulaşmasını sağlayarak hazırlanan programın başarıya ulaşmasına destek olur (Fidan, 2008; Sönmez, 2005). Bu da etkili bir eğitim-öğretim süreci için oldukça önemlidir.

Materyal kullanımında dikkat edilmesi gereken önemli noktalardan biri, öğretmenin öğrenme ortamlarında öğretim materyallerini etkin kullanabilme yeterliliğine sahip olmasıdır (Allwright, 1981; Toprakçı, 2007). Çünkü materyallerin etkili kullanımı için belirli bir düzeyde bilgi ve beceri gerekmektedir (Fidan, 2008). Öğretim ortamında ne tür materyal kullanılırsa kullanılsın materyalin nasıl kullanıldığı daha önemlidir (Semerci, 2006; Avcıoğlu, 2012). Öğretmenlerin materyalleri hazırlarken veya seçerken bu materyallerin öğretim ortamındaki işlevlerini, temel kullanım ilkelerini, yarar ve sınırlıık düzeylerini iyi bilmelerinin gerekliliği vurgulanmaktadır (Gündüz ve Odabaşı, 2004; Demiralp, 2007). Öğretmenlerin öğretim ortamında kullanacağı materyalleri belirlerken öncelikle ihtiyaçları belirlemeleri, gelecekte hangi materyalleri etkin olarak kullanacaklarına karar vermeleri (Ellis, 1997) sonrasında eğitim-öğretim ortamlarında bulunan mevcut kaynakları gözden geçirerek kaynakları en etkin şekilde nasıl kullanabilecekleri ve ortamda bulunmayan materyalleri kendi imkânlarıyla hazırlama olanaklarının olup olmadığını araştırmaları gerekmektedir. Öğretmenlerin öğretim sürecinde kullanmayı planladığı bu materyaller gerçek materyaller olabileceği gibi gerçeği modelleyen tarzda hazırlanmış materyaller de olabilir (Demiralp, 2007). Hazırlanan materyallerin sadece tek bir derse yönelik değil diğer derslerde de kullanılabilecek özellikte olması, hem esnek hem de disiplinlerarası bir öğretim ortamının oluşmasını desteklemektedir (Sevim, 2014). Öğretmenlerin bu şekilde esnek öğretim materyalleri kullanmaları, bireysel öğrenmelerini karşılarken işbirlikli çalışmalar yapmalarına da fırsat sunmaktadır. Eğitimde materyal kullanılmasının temel amacı; öğrencilerin farklı öğrenme stillerini dikkate alarak kalıcı öğrenmeyi sağlayacak ortam oluşturmak, öğrendiklerini kalıcı hale getirerek akademik başarılarını yükseltmektir (McLoughlin, 1999). Bu amacın gerçekleştirilebilmesi için 
öncelikle öğretmenlerin bu konuda yeterli donanıma sahip olmaları gerekmektedir. Öğretmenlerin yeterli donanıma sahip olması için, öncelikle göreve başlamadan önce lisans eğitiminde gerekli bilgi ve donanımın kazandırılması gerekmektedir. Görev başındaki öğretmenlere ise materyallerin hazırlanması, kullanılması, değerlendirilmesine yönelik olarak hizmet içi kursların düzenlenmesi gerektiği ifade edilmektedir (Semerci, 2006). Öğretmenlerin büyük bir kısmı materyal olarak sadece ders kitaplarını ve tahtayı kullanmakta, diğer materyalleri kullanmamaktadır. Bunun başlıca nedenleri arasında öğretmenlerin önyargıları, materyali kullanmayı bilmemeleri, özgüven eksikliği vb. durumlar gösterilmektedir (Küçükahmet, 2000). Üniversitelerde öğrenim gören öğretmen adaylarının ÖTMT dersini teorik olarak işlemelerinin önüne geçilerek uygulamaya yönelik çalışma yapmaları, derse uygun güncel teknolojileri kullanmayı bu ders kapsamında öğrenmeleri gerekmektedir (Gündüz ve Odabaşı, 2004). Meslekte verim elde edebilmek için, öğretmen adaylarııın mesleğe başlamadan önce materyal kullanımına ilişkin görüşlerinin alınmasının önemli olduğu düşünülmektedir. Bu araştırmanın amacı, öğretmen adaylarının "Öğretim Teknolojileri ve Materyal Tasarımı" dersine ilişkin görüşlerini belirlemektir. Bu amaç doğrultusunda, aşağıdaki sorulara cevap aranmıştır:

Öğretmen adaylarının;

1. ÖTMT dersinde hazırlanan öğretim materyalinin taşıması gereken özelliklere ilişkin görüşleri nelerdir?

2. ÖTMT dersinde öğretim materyalinin planlama, uygulama ve değerlendirme aşamalarında dikkat edilmesi gerekenlere ilişkin görüşleri nelerdir?

3. ÖTMT dersinin öğretim materyali hazırlama boyutunun kendilerine sağladığı katkılara ilişkin görüşleri nelerdir?

4. ÖTMT dersinde öğretim materyalini hazırlama, uygulama ve değerlendirme boyutlarında yaşanan problemlere ilişkin görüşleri nelerdir?

5. Öğretim materyali planlayan, uygulayan ve değerlendiren bir öğretmen adayının sahip olmaları gereken özelliklere ilişkin görüşleri nelerdir?

6. Lisans eğitiminde alınan ÖTMT dersinin, eğitim ortamına yönelik düşüncelerine etkisine ilişkin görüşleri nelerdir?

7. Okullarda öğretim materyallerinin kullanımına ilişkin görüşleri nelerdir?

\section{YÖNTEM}

Araştırmanın bu bölümünde; araştırmanın modeli, çalışma grubu, veri toplama araçları, verilerin toplanması ve analizi hakkında bilgilere yer verilmiştir.

\section{Araştırma modeli:}

Nitel araştırma yönteminin kullanıldığı bu araştırmada, bir durumun derinlemesine çalışmasına imkân sağlayan durum çalışması deseni kullanıımıştır. Yıldırım (1999) nitel araştırmayı; bilgi elde etmek için gözlem, görüşme ve doküman analizi vb. tekniklerin kullanıldığı, algıların ve olayların kendi doğal ortamlarında gerçekçi ve bütüncül olarak belirlenmesi için izlenen bir süreç olarak tanımlamaktadır. Glaser ve Strauss (1967) nicel tekniklerin açıklamakta yetersiz kaldığı sosyal olgular, değişim ve hareketliliğin daha doğru olarak tespit edilebilmesi için nitel araştırma yöntemlerinin kullanılması gerektiğini ifade etmektedir. Nitel araştırma teknikleri, ölçümden daha çok açıklamayı olanaklı kılacak olay ve olguların içinde gerçekleştiği durumu dikkate almayı önemsemektedir (Yıldııım ve Şimşek, 2005).

\section{Çalışma Grubu:}

Araştırmanın çalışma grubu, 2016-2017 yılı eğitim-öğretim yılı bahar döneminde Cumhuriyet Üniversitesi Eğitim Fakültesi'nde öğrenim görmekte olan 50 öğretmen adayından oluşmaktadır. Öğretmen adaylarının seçiminde, ÖTMT dersini almış olmaları ve araştırmaya 
katılmaya gönüllü olmalarına dikkat edilmiştir. Çalışma grubuna ilişkin bilgilere Tablo 1'de yer verilmiştir.

\section{Tablo 1:}

Çalışma grubuna ilişkin betimsel istatistikler

\begin{tabular}{llll}
\hline Katılımcı özellikleri & & $\mathbf{f}$ & $\%$ \\
\hline \multirow{2}{*}{ Cinsiyet } & Kadın & 37 & 74,0 \\
& Erkek & 13 & 26,0 \\
\hline \multirow{2}{*}{ Sınıf } & 3. Sınıf & 22 & 44,0 \\
& 4. Sinıf & 28 & 56,0 \\
\hline \multirow{2}{*}{ Toplam } & & 50 & 100,0 \\
\hline
\end{tabular}

Tablo 1 incelendiğinde; çalışma grubunun 37'sinin kadın, 13'ünün erkek öğretmen adaylarından oluştuğu ve 22 'sinin üçüncü sınıfta, $28^{\prime}$ inin dördüncü sınıfta öğrenim gördüğü görülmektedir.

\section{Veri Toplama Araçları:}

Nitel araştırma yöntemleri arasında en sık kullanılanları teknikler, gözlem ve görüşmedir. Bu yöntemlerin avantajlı yönleri arasında araştırılan konu ve olguları ilgili bireylerin bakış açısından tespit edilmesine imkân vermesi ve bu bakış açılarının ortaya çıkmasını sağlayan toplumsal yapıları ve süreçleri belirlemeyi sağlamasıdır (Glaser ve Strauss, 1967). Görüşme tekniğinin kullanıldığı araştırmada, veri toplama aracı olarak yedi sorudan oluşan yarı yapılandırılmış görüşme formu kullanılmıştır. Görüşme tekniği, en az iki kişi arasında sürdürülen ve bireylerin belirli bir konuya ilişkin duygu ve düşüncelerini belirlemeye yönelik olarak kullanılan bir tekniktir (Kaptan, 1973). Görüşme tekniğinin hem nicel hem de nitel araştırmalara uygun olduğu belirtilmesine rağmen (Kaptan, 1973; Sönmez ve Alacapınar, 2011), ağırlıklı olarak nitel araştırmalarda kullanıldığı görülmektedir (Yıldııım ve Şimşek, 2005). Nitel araştırmalarda kullanılan görüşme formu aracılığıyla, ilgili konunun birbiriyle ilişkili yönlerini, çelişkilerini ve tutarlılıklarını belirlemek amaçlanmaktadır (Büyüköztürk, Kılıç Çakmak, Akgün, Karadeniz ve Demirel, 2014). Büyüköztürk (2010) yarı yapılandırılmış görüşmeyi, hem sabit seçenekli cevaplamayı hem de konuyu derinlemesine irdelemeyi birleştiren bir teknik olarak ifade etmektedir. Yarı yapılandırılmış görüşme formunun hazırlanmasında, araştırmacılar öncelikle ilgili literatürü dikkatle incelenmiş ve taslak sorular hazırlanmıştır. Çalışma kapsamında hazırlanan sorular; alana uygunluk, dil açıklığı ve birbiriyle uyumluluk bakımından değerlendirilmesi için alanında uzman iki öğretim üyesine (Eğitim Programları ve Öğretim alanından bir Prof. Dr., bir Yrd. Doç. Dr.) uzman görüşüne sunulmuştur. Uzman görüşleri doğrultusunda; sorularda gerekli düzenlemeler yapılmış ve forma son şekli verilmiştir.

\section{Verilerin Analizi:}

Elde edilen verilerin çözümlenmesinde, içerik analizi yöntemi kullanılmıştır. Yıldırım ve Şimşek (2005) nitel çalışmalarda içerik analizi kullanılmasının temel amacının araştırma sonucunda elde edilen verilerdeki tekrar eden kelime ve temaların tespit edilmesi olduğunu ifade etmişlerdir. Araştırma verilerinin içinde tekrar eden kelime, kelime grupları veya kavramlar belirlenir (Büyüköztürk vd., 2014). Bu şekilde tespit edilen veriler düzenlenirken öncelikle veriler kodlanır, ana tema ve varsa alt temalar mümkün olduğunca net olarak tespit edilerek düzenlenir, elde edilen bulgular tanımlanarak yorumlanır (Yıldırım ve Şimşek, 2005; Patton, 2014). Araştırma kapsamında katılımcılardan elde edilen veriler iki ayrı araştırmacı tarafından dikkatle incelenerek kodlanmış ve sonrasında bu kodlamalar bir araya getirilerek ortak kodlamalar belirlenmiştir. Kodlamalar sırasında bazı sorularda verilerin birkaç alt başlıkta olduğu görülmüş ve bu şekildeki kodlamalar bir araya getirilerek alt temalar oluşturulmuştur. Yapılan kodlamalar araştırmacılar tarafından bir kaç hafta sonra tekrar gözden geçirilmiş ve gerekli düzenlemeler yapılmıştır. Kodlamalarda gizlilik ilkelerine uygun olarak katılımcıların bilgilerine yer verilmemiş, her birine kod numarası verilmiş, kız ve erkek öğrenci olduklarını belirten harf kullanılmıştır. Örneğin; "Ö1-K" şeklinde kodlanan 
katıımcı 1 kod numarasına sahip öğrenci ve cinsiyeti kız olarak tanımlanmıştır. Öncelikle belirlenen kodlamalar ile uygun olarak tablolar yapılmış, daha sonra iki hafta ara verilerek kodlamalar bir kez daha gözden geçirilmiş ve uzman görüşüne sunulmuştur. Elde edilen verilerin hem tekrar gözden geçirilmesi hem de uzman görüşünün alınması sayesinde, veriler üzerinde tekrar düşünülerek gözden kaçırılan noktalar varsa tespit edilmiş, daha derinlemesine fikirlerin ortaya çıkması amaçlanmıştır (Creswell, 2016).

\section{BULGULAR VE YORUMLAR}

Bu bölümünde, araştırmanın amaçları doğrultusunda ÖTMT dersine ilişkin öğretmen adaylarının görüşlerinden elde edilen bulgulara ve bu görüşlerin oluşmasına kaynaklık eden doğrudan alıntılara yer verilmiştir.

\section{1. ÖтMT Dersinde Hazırlanan Öğretim Materyalinin Özelliklerine ilişskin Görüşler}

Öğretmen adaylarına "ÖTMT dersinde hazırlanan öğretim materyalinin sizce ne gibi özellikler taşıması gerekmektedir?" sorusu sorulmuş ve katılımcılardan elde edilen veriler analiz edilerek kodlanmıştır. Elde edilen kodlamalar ve yükleme sayıları Tablo 2'de yer almaktadır.

Tablo 2:

ÖTMT dersinde hazırlanan öğretim materyalinin özelliklerine ilişkin görüşler

\begin{tabular}{lc}
\hline Katılımcı görüşleri & $\mathbf{f}$ \\
\hline Öğrenci seviyesine uygun olmalı & 35 \\
Kullanışlı olmalı & 30 \\
Amaca uygun olmalı & 24 \\
Kalıı öğrenmeyi sağlamalı & 21 \\
Dikkat çekici olmalı & 18 \\
Açık ve anlaşılır olmalı & 16 \\
Ekonomik olmalı & 11 \\
Konuya uygun olmalı & 9 \\
Geçerliği ve güvenirliği yüksek olmalı & 9 \\
Öğrenicinin aktif olmasını sağlamalı & 9 \\
Bilgiyi somutlaştırmalı & 8 \\
Dayanıklı olmalı & 7 \\
Birden fazla duyuya hitap etmeli & 6 \\
Güncel olmalı & 2 \\
Dönüt ve düzeltme imkânı vermeli & 1 \\
Eğlenceli olmalı & 1 \\
Materyal tek derse değil birden çok derse hitap etmeli & 1 \\
Toplam & $\mathbf{2 0 8}$ \\
\hline
\end{tabular}

Tablo 2 incelendiğinde; ÖTMT dersinde hazırlanan öğretim materyallerinin taşıması gereken özelliklere ilişkin olarak öğretmen adaylarının en fazla "Öğrenci seviyesine uygun olmalı" $(f=35)$, "Kullanışlı olmalı" ( $f=30)$, "Amaca uygun olmalı" ( $f=24)$, "Kalıcı öğrenmeyi sağlamalı" ( $f=21)$, "Dikkat çekici olmalı" ( $f=18)$, "Açık ve anlaşılır olmalı" ( $f=16)$, "Ekonomik olmalı" $(f=11)$ kategorilerine yükleme yaptığı görülmektedir. Bu görüşlerin oluşmasına kaynaklık eden ifadelerden örneklere aşağıda yer verilmiştir.

Ö1-K: "Öncelikle derse ilgiyi artırmalı ve dikkati çekici olmalı. Ders için hedeflenen kazanım/kazanımlara uygun olmalı. Hitap ettiği öğrencinin seviyesine uygun, kalıcı öğrenmeyi sağlayan özellikte olmalı. Var olan malzemelerle hazırlanabilecek şekilde ekonomik, pratik ve uzun süre kullanulabilecek şekilde olmalı."

Ö13-K: "Açık, anlaşılır ve ögrenci seviyesine uygun olmalı. Birden çok duyuya hitap etmeli, eğlenceli olmalı."

Ö22-E: "Amaca hizmet eden, konu ve içeriğe uygun, öğrencinin seviyesine uygun, eğlenceli ve çok amaçlı yani birkaç derste kullanılabilen özellikte olmalıdır." 
Ö46-E: "Dikkat çekici olmalıdır. Kırılma, bozulma gibi özelliklerden uzak, dayanıklı olmalı. Dersin konusuna uygun olarak hazırlanmış, maliyeti düşük ve öğrencinin seviyesine göre olmalıdır."

Görüldüğü gibi, öğretmen adaylarının çoğunluğu ÖTMT dersinde hazırlanan öğretim materyalinin özellikle öğrenci seviyesine uygun olması, kullanışlı olması, amaca uygun olması, kalıcı öğrenmeyi sağlaması gerektiğine vurgu yapmıştır.

\section{2. ÖтмT Dersinde Öğretim Materyalinin Planlama, Uygulama ve Değerlendirme Aşamalarında Dikkat Edilmesi Gerekenlere İlişkin Görüşler}

Araştırma kapsamında öğretmen adaylarına yöneltilen "Bir öğretmen adayının ÖTMT dersinde öğretim materyalinin planlama, uygulama ve değerlendirme aşamalarında nelere dikkat etmesi gerekmektedir? sorusuna ilişkin olarak elde edilen veriler kodlanmıştır. Elde edilen kodlamalar ve yükleme sayıları Tablo 3'te yer almaktadır.

Tablo 3:

ÖTMT dersinde öğretim materyalinin planlama, uygulama ve değerlendirme aşamalarında dikkat etmesi gerekenlere ilişkin görüşler

\begin{tabular}{lr}
\hline Katılımcı görüşleri & $\mathbf{f}$ \\
\hline Planlama aşamasında & $\mathbf{1 5 4}$ \\
Hedefe uygun olmasına & 50 \\
Öğrenci seviyesine uygun olmasına & 25 \\
Konuya ve derse uygun olmasına & 16 \\
Kullanışlı olmasına & 13 \\
Ilgi çekici olmasına & 9 \\
Ekonomik olmasına & 9 \\
Ön araştırmanın iyi yapıımasına & 8 \\
Hazırlanmasının kolay olmasına & 6 \\
Kullanım süresine & 5 \\
Sınıfın fiziki şartlarının uygun olmasına & 4 \\
Dönüt ve düzeltme sağlamasına & 3 \\
Güvenlik tedbirlerinin alınmasına & 3 \\
Öğrenci görüşlerinin alınmasına & 2 \\
Farklı konularla ilişkilendirilebilmesine & 1 \\
Uygulama aşamasında & $\mathbf{5 6}$ \\
Materyalin iyi tanıtılmasına & 20 \\
Öğrenci tarafından kullanılabilmesine & 16 \\
Öğrencinin dikkatini sağlamasına & 9 \\
Zamanında uygun dönüt ve düzeltme vermesine & 9 \\
Öğretmenin derste materyali etkin şekilde kullanabilmesine & 9 \\
Değerlendirme aşamasında & 2 \\
Hedefe ulaşı̆ıp ulaşımadığını değerlendirmesine & $\mathbf{6 8}$ \\
Objektif değerlendirilme yapılmasını sağlamasına & 30 \\
Dönüt ve düzeltme yapılmasını sağlamasına & 18 \\
Görsel özelliklerinin ilgi çekip çekmediğini belirlemesine & 7 \\
Kullanışlığının değerlendirilmesine & 7 \\
Özdeğerlendirme anketi uygulanmasına & 4 \\
Toplam & 2 \\
\hline
\end{tabular}

Tablo 3 incelendiğinde; öğretmen adaylarının ÖTMT dersinde öğretim materyalinin planlama aşamasında dikkat etmesi gereken özelliklere ilişkin olarak en fazla "Hedefe uygun olmasına" ( $f=50)$, "Öğrenci seviyesine uygun olmasına" $(f=25)$, "Konuya ve derse uygun olmasına" $(f=16)$, "Kullanışlı olmasına" ( $f=13)$ kategorilerine yükleme yaptıkları görülmektedir. Öğretmen adaylarının görüşlerinden örnek ifadeler aşağıda yer almaktadır.

Ö6-E: "Planlama aşmasında amaca yönelik olmalı, öğrenci seviyesi dikkate almalı, kullanım zamanı ve sınıfın şartlarını dikkate almalıdır."

Ö14-K: "Hangi ders veya konu için hazırlanıyorsa onun amaçların gerçekleştirmesine, ögrencilerin seviyelerin altında veya üstünde olmamasına." 
Ö27-K: "Materyalin amaca hizmet etme derecesi ve konuya ne gibi katkı sağlayacak tespit edilmelidir. Öğrenci seviyesi ve sınıfın şartlarına bakılmalıdır. Ayrıca ekonomik ve pratik malzemeler kullanılmalıdır."

Ö48-E: "Öncelikle öğretim programında yer alan kazanımlara ve ögrrencinin seviyesine, sınıfın fiziki şartlarına uygun olarak planlanmalıdır."

ÖTMT dersinde öğretim materyalinin uygulama aşamasında dikkat edilmesi gerekenlere ilişkin öğretmen görüşlerinin, en fazla "Materyalin iyi tanıtılmasına" ( $f=20)$, "Öğrenci tarafından kullanılabilmesine" ( $f=16)$, "Öğrencinin dikkatini sağlamasına" ( $f=9)$ kategorilerinde yoğunlaştığı görülmektedir. Bu görüşe kaynaklık eden öğretmen adaylarının örnek ifadelerine aşağıda yer verilmiştir.

Ö5-K: "Uygulama aşamasında planladı̆̆ materyali öğrenciye doğru bir şekilde tanıtmalı ve öğrencinin de materyali kullanabilmesini saplamalıdır."

Ö7-E: "Uygularken ne zaman kullanılması gerekiyorsa o zaman kullanılmalı ve ögrenciye ögrendiklerine ilişkin dönüt vermelidir."

Ö36-K: "Materyali öğrenciye tam olarak tanıtmalı, bilgi vermeli ve onun da kullanmasını sağlamalıdır. Uygulamanın sonunda gerekli dönütleri vermelidir."

ÖTMT dersinde öğretim materyalinin değerlendirme aşamasında ise öğretmen adaylarının en fazla yükleme yaptıkları kategorilerin "Hedefe ulaşılıp ulaşılmadığını değerlendirmesine" ( $f=30)$ ve "Objektif değerlendirme yapılmasını sağlamasına" $(f=18)$ olduğu tespit edilmiştir. Öğretmen adaylarının görüşlerinden örnek ifadeler aşağıda yer almaktadır.

Ö32-K"Değerlendirme aşamasında materyal üzerinden ulaşılmak istenen hedeflere ulaşılıp ulaşılmadığı ve ulaşıldıysa ne ölçüde ulaşıldığına bakılmalıdır."

Ö46-E: "Süreçte aksayan, öğrenmeyi sekteye uğratan, anlaşılmayı zorlaştıran unsurlar belirlenerek kazanımlara ne kadar ulaşıldığının belirlenmesi gerekmektedir. Eksik ve yanlış ögrrenmelere ilişkin dönüt ve düzeltme yolları etkin olarak kullanılmalıdır."

Ö50-K: "Değerlendirme aşamasında tarafsız olarak objektif bir bakış açısına sahip olunmalıdır."

ÖTMT dersinde öğretim materyalinin planlama aşmasında dikkat etmeleri gereken özelliklere yönelik olarak öğretmen adaylarının tamamının hedefe uygun olması gerektiğini ifade ettikleri; daha sonra ise sırasıyla öğrenci seviyesine uygun olması, konuya ve derse uygun olması, kullanışlı olması gerektiğine vurgu yaptıkları görülmektedir. Uygulama aşamasında; materyalin iyi tanıtılması, öğrenci tarafından kullanılabilmesi ve öğrencinin dikkatini çekmesi gerektiği görüşlerinin öne çıktığı tespit edilmiştir. Öğretim materyalinin değerlendirme aşamasında ise materyalin hedefe ulaşılıp ulaşımadığını değerlendirmesi, değerlendirmenin objektif yapılmasını sağlaması en çok üzerinde durulan görüş olmuştur.

\section{3. ÖTMT Dersinin Öğretim Materyali Hazırlama Boyutunun Katkılarına ilişskin Görüşler}

Araştırma amaçları doğrultusunda öğretmen adaylarına yöneltilen "ÖTMT dersinin öğretim materyali hazırlama boyutunun öğretmen adaylarına sağladı̆ı katkılar nelerdir? sorusuna ilişkin olarak elde edilen veriler kodlanmış ve yükleme sayıları Tablo 4 'te sunulmuştur.

Tablo 4 incelendiğinde; öğretmen adaylarının ÖTMT dersinin öğretim materyali hazırlama boyutunun bilişsel, duyuşsal, devinişsel ve sosyal alanda katkılar sağladığı katkılara ilişkin görüşlerinin yer aldığı görülmektedir. ÖTMT dersinin öğretim materyali hazırlama boyutunun bilişsel alana katkılarına ilişkin olarak en fazla yükleme yaptıkları kategorilerin "Üst düzey düşünme becerilerini geliştirecek materyaller hazırlamayı öğrenme" ( $f=22$ ), "Bilgiyi daha iyi kavratmayı sağlayacak materyalleri hazırlamayı öğrenme" ( $f=19)$, "Birden fazla duyu organını 
kullanılmasını sağlayacak materyaller hazırlamayı öğrenme" (f=12), "Kalıcı öğrenmeyi sağlayan materyaller hazırlamayı öğrenme" ( $f=12)$ olduğu görülmektedir.

Tablo 4:

ÖTMT dersinin öğretim materyali hazırlama boyutunun katkılarına ilişkin görüşler

\begin{tabular}{|c|c|}
\hline Katılımcı Görüşleri & $\mathbf{f}$ \\
\hline Bilişsel alana katkıları & 102 \\
\hline Üst düzey düşünme becerilerini geliştirecek materyaller hazırlamayı öğrenme & 22 \\
\hline Bilgiyi daha iyi kavratmayı sağlayacak materyalleri hazırlamayı öğrenme & 19 \\
\hline Birden fazla duyu organını kullanıımasını sağlayacak materyaller hazırlamayı öğrenme & 12 \\
\hline Kalıı öğrenmeyi sağlayan materyaller hazırlamayı öğrenme & 12 \\
\hline Bilgiyi aktarabilen materyaller hazırlamayı öğrenme & 10 \\
\hline Bilgiyi somutlaştıran materyaller hazırlamayı öğrenme & 9 \\
\hline Hatırlamayı kolaylaştıracak materyalleri hazırlamayı öğrenme & 5 \\
\hline Dersin işlenmesini kolaylaştıran materyaller hazırlamayı öğrenme & 5 \\
\hline Amacına hizmet eden materyaller hazırlamayı öğrenme & 2 \\
\hline Farklı materyal hazırlama tekniklerini kullanmayı öğrenme & 2 \\
\hline Materyal hazırlama kurallarını uygulayarak materyal hazırlamayı öğrenme & 2 \\
\hline Planlayarak materyal hazırlamayı öğrenme & 1 \\
\hline Yeni bilgileri eski bilgilerle ilişkilendiren materyaller hazırlamayı öğrenme & 1 \\
\hline Duyuşsal alana katkıları & 44 \\
\hline Materyal hazırlamaya yönelik dikkatini ve ilgisini çekme & 12 \\
\hline Materyal hazırlamaya ilişkin olumlu tutum kazanmasını destekleme & 12 \\
\hline Materyal hazırlamaya ilişkin özgüven duygusunun gelişimini sağlama & 8 \\
\hline Demokratik tutum ve anlayış kazandırma & 3 \\
\hline Materyal hazırlamaya ilişkin motivasyonunun artmasını sağlama & 2 \\
\hline Materyal hazırlamaya yönelik estetik boyutunun gelişmesini sağlama & 2 \\
\hline Kendi yapabileceklerinin farkına varmasını sağlama & 2 \\
\hline Çocukların düşüncelerini daha kolay anlamayı sağlama & 2 \\
\hline Materyal hazırlarken sevgi, saygı vb. alanlarda farkındalığının oluşmasını sağlama & 1 \\
\hline Devinişsel alana katkıları & 47 \\
\hline Psikomotor becerilerini geliştirme & 28 \\
\hline Kas gelişimini destekleme & 10 \\
\hline Materyali doğru ve etkili kullanma becerisini geliştirme & 9 \\
\hline Sosyal alana katkıları & 60 \\
\hline Sosyalleşmeyi sağlama & 22 \\
\hline İşbirlikli çalışmayı öğrenmeyi sağlama & 21 \\
\hline İletişim becerisini geliştirmeyi sağlama & 12 \\
\hline Hazırladıkları materyalleri bir grup karşısında uygulama imkânı bulmasını sağlama & 3 \\
\hline Toplumdaki farklı kesimler hakkında bilgi edinmesini sağlama & 2 \\
\hline Toplam & 253 \\
\hline
\end{tabular}

Öğretmen adaylarının bilişsel alana katkılarına kaynaklık eden örnek ifadelerine aşağıda yer verilmiştir.

Ö2-K: "Çok boyutlu düşünerek metabiliş gibi üst düzey düşünme becerilerini geliştirir."

Ö5-E: "Üst düzey düşünmeyi sağlayarak kavramayı kolaylaştırır. Öğrencinin bilgiyi daha iyi kavramasını sağlayacak, kalıcı ögrenmesini destekleyecek materyal hazırlama"

Ö36-K: "Kavratmayı ve kalıcı öğrenmeyi sağlayan farklı duyu organlarına hitap eden materyalleri hazırlamayı öğretir."

Ö48-E: "Düşünme becerilerini geliştirir. Birden fazla duyu organına hitap edecek materyal hazırlamayı ögretir."

Öğretmen adaylarının ÖTMT dersinin öğretim materyali hazırlama boyutunun duyuşsal alana katkılarına ilişkin görüşlerinde en fazla yükleme yapılan kategorilerin "Materyal hazırlamaya yönelik dikkatini ve ilgisini çekme" ( $f=12)$, "Materyal hazırlamaya ilişkin olumlu tutum kazanmasını destekleme" ( $f=12)$, "Materyal hazırlamaya ilişkin özgüven duygusunun gelişimini sağlama" $(f=8)$ olduğu tespit edilmiştir. Bu görüşlere kaynaklık eden öğretmen adaylarının ifadelerinden örneklere aşağıda yer verilmiştir. 
Ö4-K: "Duyuşsal alanda materyal hazırlamaya ilişkin olarak ilgi duymaya başlar ve materyal hazırlamaya yönelik motivasyonunu arttırı."

Ö22-E: "Özgüven oluşmasına yardımcı olur."

Ö38-K: "Materyal hazırlamaya ilişkin daha dikkatli ve olumlu bir tutum kazandırır. Aynı zamanda farklı görüşlere saygı duyarak demokratik tutumun gelişimini de sağlar."

ÖTMT dersinin öğretim materyali hazırlama boyutunun devinişsel alana katkılarına ilişkin öğretmen görüşlerinde en fazla yüklemenin "Psikomotor becerilerini geliştirme" ( $f=28)$, "Kas gelişimini destekleme" ( $f=10)$, "Materyali doğru ve etkili kullanma becerisini geliştirme" ( $f=9)$ kategorilerine yapıldığı belirlenmiştir. Öğretmen adaylarının görüşlerinden örnek ifadeler aşağıda sunulmaktadır.

Ö15-E: "Kas gelişimini destekler."

Ö21-E: "Psikomotor becerilerin gelişmesini sağlayarak kas gelişimini destekler."

Ö45-K: "Hazırladığı materyali doğru ve etkili kullanmasını ve motor becerilerin gelişimini destekler."

Son olarak, ÖTMT dersinin öğretim materyali hazırlama boyutunun sosyal alanda katkılarına ilişkin öğretmen görüşlerine bakıldığında; en fazla yüklemenin "Sosyalleşmeyi sağlama" (f=22), "Işsirlikli çalışmayı öğrenmeyi sağlama" ( $f=21)$, "iletişim becerisini geliştirmeyi sağlama" $(f=12)$ kategorilerine yapıldığı görülmektedir. Öğretmen adaylarının görüşlerinden örnek ifadelere aşağıda yer verilmiştir.

Ö9-K: "Grupla çalışıldığı için sosyalleşmeyi arttırır."

Ö15-E: "Işbirlikli çalışmayı ögretir."

Ö31-K: "Sürekli birlikte çalışıldığı için iletişim becerisinin daha iyi olmasını sağlar."

Ö43-K: "Çevredeki diğer insanlarla iletişim kurulmasını ve daha fazla sosyalleşmeyi, toplumdaki farklı kesimlere ilişkin bilgi edinilmesini sağlar."

Genel olarak değerlendirildiğinde; ÖTMT dersinin öğretim materyali hazırlama boyutunun bilişsel alanda katkılarının üst düzey düşünme becerilerini geliştirecek materyaller hazırlamayı öğrenme, bilgiyi daha iyi kavratmayı sağlayacak materyalleri hazırlamayı öğrenme; duyuşsal alanda katkılarının materyal hazırlamaya yönelik dikkatini ve ilgisini çekme, materyal hazırlamaya ilişkin olumlu tutum kazanmasını destekleme olarak öne çıtığı görülmektedir. Öğretmen adaylarının devinişsel alanda katkılarının psikomotor becerilerini geliştirme, kas gelişimini destekleme; sosyal alanda katkılarının ise sosyalleşmeyi sağlama, işbirlikli çalışmayı öğrenmeyi sağlama olarak öne çıktığı belirlenmiştir.

\section{4. Ӧтмт Dersinin Öğretim Materyalini Hazırlama, Uygulama ve Değerlendirme Boyutlarında Yaşanan Problemlere iliş̧kin Görüşler}

Araştırma kapsamında öğretmen adaylarına sorulan "ÖTMT dersinde ögretim materyalini hazırlama, uygulama ve değerlendirme boyutlarında ne tür problemler yaşamaktadır?" sorusuna ilişkin olarak elde edilen bulgular kodlanmış ve bu kodlamalara ilişkin bulgulara Tablo $5^{\prime}$ te yer verilmiştir. 


\section{Tablo 5:}

ÖTMT dersinin ögrretim materyalini hazırlama, uygulama ve değerlendirme boyutlarında yaşanan problemlere ilişkin görüşler

\begin{tabular}{lc}
\hline Katılımcı Görüşleri & $\mathbf{f}$ \\
\hline Hazırlama & $\mathbf{9 5}$ \\
Amacına uygun hazırlayamama & 32 \\
Maliyetli olması & 15 \\
Öğrenci seviyesine uygun hazırlayamama & 14 \\
Zaman alması & 10 \\
Malzeme bulmakta sıkıntı yaşama & 10 \\
Materyal hazırlamanın zor olması & 5 \\
Iyi planlama yapamama & 4 \\
Materyal geliştirmede tecrübesiz olma & 2 \\
Yeterince bilgiye ve örneklere ulaşamama & 2 \\
Dikkat ve ilgi çekici materyal hazırlayamama & 1 \\
Uygulama boyutunda & $\mathbf{8 0}$ \\
Kullanışı olmaması & 23 \\
Öğrencinin dikkatini çekmemesi & 16 \\
Materyali kullanma konusunda bilgi eksikliğinin olması & 16 \\
Sınıfın kalabalık olması & 9 \\
Materyal uygulamanın uzun zaman alması & 7 \\
Uygulama için fiziki şartların uygun olmaması & 4 \\
Sınıf kontrolünü sağlayamama & 2 \\
Güvenlik önlemlerinin yeterince alınamaması & 2 \\
Öğrencinin materyali kullanmada isteksiz olması & 1 \\
Değerlendirme boyutunda & $\mathbf{2}$ \\
Objektif değerlendirmeyi sağlayamama & $\mathbf{3 7}$ \\
Sınıf seviyesine uygun değerlendirme yapamama & 25 \\
Farklı değerlendirme yöntemlerinin kullanamama & 8 \\
Uygun dönüt ve düzeltme yapamama & 2 \\
Toplam & 2 \\
\hline
\end{tabular}

Tablo 5 incelendiğinde; ÖTMT dersinin öğretim materyalini hazırlama, uygulama ve değerlendirme boyutlarında yaşanan problemlere ilişkin bulguların yer aldığı görülmektedir. Öğretmen adaylarının ÖTMT dersinde öğretim materyalinin hazırlama boyutuna ilişkin verdikleri yanıtlarda en fazla yüklemelerin "Amacına uygun hazırlayamama" ( $f=32)$, "Maliyetli olması" $(f=15)$, "Öğrenci seviyesine uygun hazırlayamama" ( $f=14)$, "Zaman alması" $(f=10)$, "Malzeme bulmakta sıkıntı yaşama" ( $f=10)$ şeklinde sıralandığı görülmektedir. Bu boyutun oluşmasına kaynaklık eden öğretmen adaylarının ifadelerinden örneklere aşağıda yer verilmiştir.

Ö3-K: "Hazırlanan materyal dersin amaçlarına uygun özellikte olmayabilir ve materyali hazırlayacağı araç-gereçleri bulmakta sıkıntı olabilir."

Ö8-K: "Amaca uygun olmaması, ekonomik olmaması, öğrenci özelliklerine uygun olmaması."

Ö27-K: "Amaca en uygun materyalin hazırlanması, materyalin hazırlanacağı malzemelerin bulunup bulunamayacağı ve maliyeti ile ilgili endişeler."

Ö39-E: "Amaca uygun materyal hazırlamanın zorluğu ve zaman alması, ekonomik olarak yaşanan sıkıntılar, materyali hazırlarken gerekli bilgilerin yetersizliği..."

ÖTMT dersinin öğretim materyalini uygulama boyutunda; en fazla yüklemenin "Kullanışlı olmaması" ( $f=23)$, "Öğrencinin dikkatini çekmemesi" $(f=16)$, "Materyali kullanma konusunda bilgi eksikliğinin olması" ( $f=16)$, "Sınıfın kalabalık olması $(f=9)$ kategorilerine yapıldığı görülmektedir. Uygulama boyutunun oluşmasına kaynaklık eden öğretmenlerin ifadelerinden örneklere aşağıda yer verilmiştir.

Ö10-K: "Dersin amacına uygun, öğrencinin dikkatini çekecek materyal tasarlamanın zor olması. Hazırlanan materyalin kullanışlı olmaması, sınıfın çok kalabalık olması..." 
Ö17-K: "Hazırlanan materyal hakkında bilgi eksikliği olması ve sonucunda kullanışlı bir materyalin tam olarak ortaya çıkmaması. Kullanırken de çok fazla zaman harcanabilir. Sınıflarda bu materyalleri uygulamak için çoğunlukla şartlar da elverişsiz durumda."

Ö27-K: "Materyali kullanırken gereken tecrübede eksilikler olduğu için tam olarak kullanılamaması. Sınıf mevcudunun fazla olması ve güvenlik önlemlerinin yetersizliği."

ÖTMT dersinin öğretim materyalini değerlendirme boyutunda öğretmen adaylarının en fazla da "Objektif değerlendirmeyi sağlayamama" $(f=25)$, "Sınıf seviyesine uygun değerlendirme yapamama" ( $f=8)$ kategorilerine vurgu yaptığı görülmektedir. Bu boyuta kaynaklık eden öğretmen adaylarının görüşlerinden örnek ifadelere aşağıda yer verilmiştir.

ö9-K: "Sınıftaki öğrencilerin düzeyine göre değerlendirme yapılamaması"

Ö15-E: "Doğru dönüt verilmemesi. Değerlendirmede yansızlığın korunarak objektifliğin sağlanamaması."

Ö36-K: "Değerlendiren kişi yanlı davranabilir ve adil olmayan bir puanlama yapabilir."

Genel olarak değerlendirildiğinde; öğretmen adaylarının öğretim materyali hazırlama boyutunda amaca uygun hazırlayamama, maliyetli olması, öğrenci seviyesine uygun hazırlayamama; uygulama boyutunda kullanışlı olmaması, öğrencinin dikkatini çekmemesi, materyali kullanma konusunda bilgi eksikliğinin olması; değerlendirme boyutunda ise objektif değerlendirmeyi sağlayamama problemlerinin öne çıktığı söylenebilir.

\section{5. Öğretim Materyali Planlayan, Uygulayan ve Değerlendiren Bir Öğretmen Adayının Sahip Olması Gereken Özelliklere îlişkin Görüşler}

Araştırmanın amaçları doğrultusunda, öğretmen adaylarına sorulan "Sizce öğretim materyali planlayan, uygulayan ve değerlendiren bir ögretmen adayının sahip olması gereken özellikler nelerdir?" sorusu ilişkin elde edilen bulgular kodlanmış ve bu kodlamalara ilişkin bulgulara Tablo 6 'da yer verilmiştir.

Tablo 6 incelendiğinde, öğretim materyali planlayan bir öğretmen adayının sahip olması gereken özellikler arasında öğretmen adaylarının en fazla "Materyal hazırlanacak konu hakkında bilgi sahibi olmalı" ( $f=21)$, "Öğrenci seviyesini bilmeli" ( $f=18)$, "Yaratıcı düşünme becerisine sahip olmalı" ( $f=13)$, "Öğretim materyali konusunda bilgi sahibi olmalı" ( $f=11)$ özelliklerine yükleme yaptıkları tespit edilmiştir. Öğretmen adaylarının görüşlerinden örnek ifadelere aşağıda yer verilmiş̧ir.

Ö15-E: "Planlarken konuyu bilerek ona uygun materyali hazırlamalı, çeşitli zekâ türlerini hesaba katabilmeli, maliyetine dikkat etmeli ve zengin uyarıcılar sunabilmelidir."

ö18-K: "Materyal hakkında geniş bilgi sahibi olmalı, öğrencilerin seviyesine dikkat etmeli."

Ö25-K: "Öğrencilerin özelliklerinin farkında olarak onların seviyesine uygun materyal hazırlamalı, araştırma yaparak yaratıcı düşünme becerilerini kullanmalı ve kendine güvenmelidir."

Ö42-K: "Öğrenci özelliklerini ve seviyesinin farkında olmalı, çok boyutlu düşünerek iyi planlama yapabilmeli, materyal hazırlama konusunda araştırma yapmalı ve bilgi sahibi olmalıdır." 


\section{Tablo 6:}

Öğretim materyali planlayan, uygulayan ve değerlendiren bir öğretmen adayının sahip olması gereken özelliklere ilişkin görüşler

\begin{tabular}{|c|c|}
\hline Katılımcı Görüşleri & $f$ \\
\hline Planlayan & 107 \\
\hline Materyal hazırlanacak konu hakkında bilgi sahibi olmalı & 21 \\
\hline Öğrenci seviyesini bilmeli & 18 \\
\hline Yaratıcı düşünme becerisine sahip olmalı & 13 \\
\hline Öğretim materyali konusunda bilgi sahibi olmalı & 11 \\
\hline El becerisi iyi olmalı & 9 \\
\hline İyi planlama yapabilmeli & 7 \\
\hline Çok yönlü düşünebilmeli & 6 \\
\hline Maliyeti göz önünde bulundurmalı & 5 \\
\hline Zamanı etkin kullanmalı & 4 \\
\hline Araştırma yapmalı & 4 \\
\hline Pratik olmalı & 2 \\
\hline Sabırlı olmalı & 2 \\
\hline Kendine güvenmeli & 2 \\
\hline Zengin uyarıcılar sunabilmeli & 2 \\
\hline Çeşitli zekâ türlerini dikkate almalı & 1 \\
\hline Uygulayan & 93 \\
\hline Materyali uygun şekilde kullanabilmeli & 30 \\
\hline Öğrencinin aktif katılımını sağlamalı & 10 \\
\hline Güvenlik önlemi alabilmeli & 7 \\
\hline Mevcut şartları uygulamaya uygun hale getirmeli & 7 \\
\hline Materyali tanıtırken güzel ve açık bir dil kullanmalı & 6 \\
\hline Etkili iletişim becerisine sahip olmalı & 5 \\
\hline Öğrenciye rehberlik edebilmeli & 5 \\
\hline Sabırlı olmalı & 5 \\
\hline Öğrencinin dikkatini ve ilgisini çekmeli & 3 \\
\hline Düzenli olmalı & 3 \\
\hline Disiplinli olmalı & 3 \\
\hline Süreci takip edebilmeli & 3 \\
\hline Sınıf hâkimiyetini sağlamalı & 3 \\
\hline Zamanı dikkatli kullanmalı & 2 \\
\hline Pekiştireç kullanmalı & 1 \\
\hline Değerlendiren & 65 \\
\hline Objektif olmalı & 26 \\
\hline Materyalin amaca hizmet edip etmediğini değerlendirebilmeli & 18 \\
\hline Dönüt ve düzeltme vermeli & 9 \\
\hline Öğrenciyi değerlendirmeye dâhil edebilmeli & 6 \\
\hline Öz eleştiri yapabilmeli & 4 \\
\hline Çok yönlü değerlendirebilmeli & 2 \\
\hline Toplam & 265 \\
\hline
\end{tabular}

Öğretim materyali uygulayan bir öğretmen adayının sahip olması gereken özellikler arasında öğretmen adaylarının en fazla "Materyali uygun şekilde kullanabilmeli" ( $f=30$ ), "Öğrencinin aktif katılımını sağlamalı" ( $f=10)$, "Güvenlik önlemi alabilmeli" ( $f=7)$, "Mevcut şartları uygulamaya uygun hale getirmeli" ( $f=7)$, "Materyali tanıtırken güzel ve açık bir dil kullanmalı" ( $f=6$ ) özelliklerine yükleme yaptıkları belirlenmiştir. Bu görüşe kaynaklık eden öğretmen adaylarının görüşlerinden örnek ifadelere aşağıda yer verilmiştir.

Ö1-K: "Öğrenciyi derse katmalı ve disiplinli olmalı, öğrenciye zarar gelmemesi için güvenlik önlemlerini almalıdır."

Ö36-K: "Sınıfı kontrol altında tutma becerisine sahip, materyali zamanında ve etkin olarak kullanabilmelidir."

Ö39-E: "Öğrencinin aktif katılımını sağlamalı, materyali öğrencinin anlayabileceği açıklıkta tam olarak tanıtmalıdır." 
Ö46-E: "Materyal konusunda öğrencilere rehberlik yaparak nasıl kullanılacağını göstermeli, sınıfta hâkimiyeti sağlamalı, düzenli ve disiplinli olmalıdır."

Öğretim materyali değerlendiren bir öğretmen adayının sahip olması gereken özellikler arasında öğretmen adaylarının en fazla "Objektif olmalı" ( $f=26)$, "Materyalin amaca hizmet edip etmediği değerlendirebilmeli" ( $f=18$ ), "Dönüt ve düzeltme vermeli" $(f=9)$ özelliklerine yükleme yaptıkları görülmektedir. Elde edilen bulguların oluşmasına kaynaklık eden öğretmen adaylarının görüşlerinden örneklere aşağıda yer verilmiştir.

Ö15-E: "Değerlendirirken ise objektif olmalı ve bireysel farklılıların farkında olarak öğrenciyi derse katabilmeli."

Ö17-K: "Çok yönlü değerlendirme teknikleri kullanmalıdır."

Ö25-K: "Değerlendirmede hazırladığı materyalin amaca hizmet edip etmediğini objektif bir şekilde değerlendirmelidir."

Genel olarak değerlendirildiğinde; öğretim materyali planlayan bir öğretmen adayının özellikle materyal hazırlanacak konu hakkında bilgi sahibi olması, öğrenci seviyesini bilmesi; öğretim materyali uygulayan bir öğretmen adayının materyali uygun şekilde kullanabilmesi öğrencinin aktif katılımını sağlaması; öğretim materyali değerlendiren bir öğretmen adayının ise objektif olması, materyalin amaca hizmet edip etmediği değerlendirebilmesi gerektiğine ilişkin görüşlerin öne çıktığı söylenebilir.

\section{Lisans Eğitiminde Alınan ÖTMT Dersinin Eğitim Ortamına Yönelik Düşüncelerine Etkisine iliş̧kin Görüşler}

Araştırma kapsamında, öğretmen adaylarına "Lisans eğitiminizde aldığınız ÖTMT dersi eğitim ortamına yönelik düşüncelerinizi nasıl etkiledi? Neden?" sorusu yöneltilmiş ve öğretmen adaylarının görüşlerinden elde edilen bulgulara Tablo 7'de yer verilmiştir.

Tablo 7:

Lisans eğitiminde alınan ÖTMT dersine ilişkin görüşler

\begin{tabular}{|c|c|c|}
\hline \multicolumn{2}{|c|}{ Katılımcı Görüşleri } & $\mathbf{f}$ \\
\hline \multicolumn{2}{|c|}{ Olumlu etkiledi } & 57 \\
\hline \multirow{14}{*}{$\begin{array}{l}\frac{\mathbf{d}}{\mathrm{d}} \\
\frac{\mathrm{c}}{\mathrm{d}} \\
\mathbf{d} \\
\mathbf{z}\end{array}$} & Materyal hazırlamayı öğrendik. & 12 \\
\hline & Bilginin kalıcılığı konusunda materyalin büyük bir öneme sahip olduğunu fark ettik. & 9 \\
\hline & Öğrenmeyi kolaylaştırdığını öğrendik. & 6 \\
\hline & Materyalin öğretim ortamını zenginleştirdiğini öğrendik. & 5 \\
\hline & Görsel öğelerin öğrenmeyi etkilediğini öğrendik. & 4 \\
\hline & Soyut olan düşünceleri somutlaştırdığını öğrendik. & 4 \\
\hline & Dersin etkin olarak işlenmesine yardımcı olduğunu öğrendik. & 4 \\
\hline & Materyalin dikkat çekici olmasının önemini öğrendik. & 3 \\
\hline & Derse giren hocanın katkı sunması gerektiğini öğrendik. & 3 \\
\hline & Dersi eğlenceli hale getirdiğini öğrendik. & 3 \\
\hline & Öğrencileri daha iyi anlamamızı sağladığıı öğrendik. & 1 \\
\hline & Pratik, eleştirel, yaratıcı düşünce esas olarak verilmesi gerektiğini öğrendik. & 1 \\
\hline & Öğrenci seviyelerinin dikkate alınması gerektiğini öğrendik. & 1 \\
\hline & Bakış açımızı değiştirerek farklı bakış açısı geliştirdiğini öğrendik. & 1 \\
\hline \multicolumn{2}{|r|}{ Olumsuz etkiledi } & 26 \\
\hline \multirow{5}{*}{$\begin{array}{l}\frac{2}{d} \\
\frac{d}{c} \\
\frac{d}{d} \\
z\end{array}$} & Hoca derse düzenli gelmediği için verimli olmadı. & 8 \\
\hline & Dersin işlenmesi yetersiz. & 6 \\
\hline & Dersin içeriği yetersiz. & 6 \\
\hline & Teori ile sınırlı kaldı. & 6 \\
\hline & Toplam & 83 \\
\hline
\end{tabular}

Tablo 7'ye bakıldığında; lisans eğitiminde alınan ÖTMT dersine ilişkin görüşlerin "olumlu etkiledi" ( $f=57$ ) ve "olumsuz etkiledi" ( $f=26$ ) olmak üzere iki tema altında toplandığı görülmektedir. ÖTMT dersinin olumlu etkilediğini ifade eden öğretmen adaylarının nedenleri incelendiğinde ise en fazla "Materyal hazırlamayı öğrendik" ( $f=12$ ), "Bilginin kalıcılığı konusunda materyalin büyük 
bir öneme sahip olduğunu fark ettik" $(f=9)$, "Öğrenmeyi kolaylaştırdığını öğrendik" $(f=6)$, "Materyalin öğretim ortamını zenginleştirdiğini öğrendik" ( $f=5)$ nedenlerine yükleme yapıldığı belirlenmiştir. Bu görüşe kaynaklık eden öğretmen adaylarının görüşlerinden örnek ifadelere aşağıda yer verilmiştir.

Ö18-K: "Aldığımı eğitim sonucunda derslere ilișkin ne tür materyal hazırlayabileceğimizi, çocukların ilgisini nasıl çekebileceğimizi öğrendik. Materyallerde görselliğin önemini fark ettik. Bence çok yararı oldu."

Ö24-K: "Öğretim ortamını zenginleştiren, eğlenceli hale getiren, öğrenci seviyesine uygun materyalleri hazırlamayı öğrendik. Bu derste kendi yaratıclığımız daha çok gelişti."

Ö29-K: "Öğretim ortamını materyaller aracılığıla zenginleştirdiğinizde öğrenmenin daha eğlenceli ve kolay olduğunu, bilgiyi somutlaştırdığını öğrendik."

ÖTMT dersinin olumsuz etkilediğini ifade eden öğretmen adaylarının nedenleri incelendiğinde ise "Hoca derse düzenli gelmediği için verimli olmadı." ( $f=8)$, "Dersin işlenmesi yetersiz." ( $f=6)$, "Dersin içeriği yetersiz." $(f=6)$ ve "Teori ile sınırlı kaldı. $(f=6)$ " nedenlerinin dile getirildiği görülmektedir. Bu görüşe kaynaklık eden öğretmen adaylarının görüşlerinden örnek ifadelere aşağıda yer verilmiştir.

Ö21-E: "Ders hocasının derse daha fazla katkı sunmaması, dersi geçiştirmesi olumsuz etkiledi. Dersin içeriğinin de daha fazla geliştirilmesinin zorunlu olduğunu düşünüyorum."

Ö43-K: "Materyal dersinde keşke hocamız daha düzenli derse gelseydi daha fazla materyal hazırlayabilir ve bakış açımızı daha çok geliştirebilirdik."

Ö50-K: "Aldığımı eğitim sadece hocanın düz anlattıklarıyla sınırlı kaldı ve uygulamaya dönük bir çalışma yapmadık. Yani derste materyal hazırlamadık."

Genel olarak lisans eğitiminde alınan ÖTMT dersine ilişkin görüşler incelendiğinde; materyal hazırlamayı öğrenmelerini sağlaması, bilginin kalıcılığı konusunda materyalin büyük bir öneme sahip olduğunu fark etmelerini sağlaması ve öğrenmeyi kolaylaştırarak öğrenmelerini sağlaması açısından öğretmen adaylarının olumlu etkilendiğini; ancak ders hocasının derse düzenli gelmemesinden dolayı dersin verimli geçmemesi, dersin işlenişinin ve içeriğinin yetersiz olması ve dersin teori ile sınırlı kalması açısından öğretmen adaylarının olumsuz etkilendiğini söylemek mümkündür.

\section{Okullarda Öğretim Materyallerinin Kullanımına ilişkin Görüşler}

Araştırmada son olarak, öğretmen adaylarına "Okullarda öğretim materyallerinin kullanımına ilişkin görüşleriniz nelerdir? Neden?" sorusu yöneltilmiş ve öğretmen adaylarının görüşlerinden elde edilen bulgulara Tablo 8'de yer verilmiştir.

Tablo 8 incelendiğinde; okullarda öğretim materyallerinin kullanımına yönelik olarak öğretmen adaylarının tamamı kullanılmalı yönünde görüş bildirmiştir. Öğretmen adaylarının önemli bir kısmının okullarda materyal kullanılması gerektiğine ilişkin düşüncelerinin gerekçesi olarak en fazla "Bilginin kalıcılığını sağlar." $(f=8)$, "Konuyu daha anlaşılır hale getirir." $(f=8)$, "Öğrenmeyi kolaylaştııı." ( $f=8)$ gerekçelerine vurgu yaptığı görülmektedir. Bu görüşe kaynaklık eden öğretmen adaylarının ifadelerinden örneklere aşağıda yer verilmiş̧ir.

Ö10-K: "Konu anlatımında materyal kullanılması ögrrencilerin derse ilgisini arttııır, öğrenmelerini kolaylaştırır ve kalıcı olmasını sağlar."

Ö14-K: "Okullarda her derste materyal kullanılması gerektiğini düşünüyorum. Bu öğrencilerin öğrenmelerini kolaylaştırır ve yaparak yaşayarak öğrenmelerini sağlar."

Ö35-K-: "En küçük bir materyalin bile öğrenmeyi kalıcı hale getirdiğini, bilgiyi somutlaştırdığını düşünürsek imkânlar doğrultusunda her okulda kullanılması gerekmektedir." 
Tablo 8:

Okullarda öğretim materyallerinin kullanımına ilişkin görüşler

\begin{tabular}{|c|c|c|}
\hline \multicolumn{2}{|c|}{ Katılımcı Yanıtları } & $\mathbf{f}$ \\
\hline \multicolumn{2}{|c|}{ Okullarda materyal kullanılmalı } & 41 \\
\hline \multirow{11}{*}{$\begin{array}{l}\frac{-}{0} \\
\frac{0}{5} \\
\frac{0}{0} \\
\text { z }\end{array}$} & Bilginin kalıcılığını sağlar. & 8 \\
\hline & Konuyu daha anlaşılır hale getirir. & 8 \\
\hline & Öğrenmeyi kolaylaştırır. & 8 \\
\hline & Konuyu ilgi çekici hale getirir. & 3 \\
\hline & Öğrencinin derse karşı güdülenmesini arttııır. & 3 \\
\hline & Öğrencilerin yaşayarak-yaparak öğrenmesini sağlar. & 2 \\
\hline & Derse katılımı artırır. & 2 \\
\hline & Eğlenceli öğrenme ortamı oluşturur. & 2 \\
\hline & Eğitim kalitesini arttıır. & 2 \\
\hline & Çocukların farklı zekâ türlerine hitap eder. & 2 \\
\hline & Çocukların düşünce dünyasını geliştirir. & 1 \\
\hline \multicolumn{2}{|r|}{ Okullarda materyal kullanılmalı, ancak kullanımı çok yetersiz. } & 16 \\
\hline \multirow{4}{*}{$\begin{array}{l}\frac{\mathbf{c}}{\mathbf{d}} \\
\frac{\mathrm{d}}{\mathrm{d}} \\
\mathbf{d} \\
\mathbf{z}\end{array}$} & Öğretmenlerimizin materyal hazırlamasını ve etkili kullanmasını bilmemesi. & 8 \\
\hline & Her konu ve ders için kullanılamaması. & 4 \\
\hline & Okulların fiziki imkânlarının yetersiz olması. & 4 \\
\hline & Toplam & 57 \\
\hline
\end{tabular}

Okullarda öğretim materyallerinin kullanımına yönelik olarak bazı öğretmen adayları ise materyalin kullanılması gerektiği ancak okullarda materyal kullanımının yetersiz olduğunu düşündüğü dile getirmiştir. Bu görüşün gerekçelerine bakıldığında; "Öğretmenlerimizin materyal hazırlamasını ve etkili kullanmasını bilmemesi" $(f=8)$, "Her konu ve ders için kullanılamaması" $(f=4)$, "Okulların fiziki imkânlarının yetersiz olması" ( $f=4)$ gerekçelerinin yer aldığı görülmektedir. Bu görüşe kaynaklık eden öğretmen adaylarının görüşlerinden örnek ifadelere aşağıda yer verilmiştir.

Ö5-E: "Çoğu okulda materyal kullanmak için gerekli ortamlar bulunmamaktadır."

Ö12-K: "Öğretmenler bu konuda yeterli bilgiye sahip olmadıkları için materyal kullanmıyor ve dersi anlatarak işliyorlar."

Ö46-E: "Stajyer öğrenci olarak okullara gidiyoruz ve kullanılması gereken materyallerin çoğu zaman okulların imkânlarının yetersiz olması bazen de ögretmenlerin materyal hazırlama hakkında yetersiz olmaları nedeniyle kullanılmadığını görüyoruz."

Genel olarak değerlendirildiğinde; öğretmen adaylarının okullarda öğretim materyali kullanılmasına ilişkin olarak olumlu görüş içerisinde oldukları söylenebilir. Olumlu görüşlerin nedenlerinin bilginin kalıcılığını sağlaması, konuyu daha anlaşılır hale getirmesi, öğrenmesi kolaylaştırması şeklinde öne çıktığı görülmektedir. Okullarda materyal kullanımının gerekli olduğunu ancak bunun çeşitli nedenlerle yetersiz olduğunu söyleyen öğretmen adayları ise bu nedenleri öğretmenlerimizin materyal hazırlamasını ve etkili kullanmasını bilmemesi, her konu ve ders için kullanılamaması ve okulların fiziki imkânlarının yetersiz olması olarak ifade etmişlerdir.

\section{SONUÇLAR VE TARTIŞMA}

Öğretim yapılan ortamlarda; eğitim-öğretim sürecini zenginleştirerek öğrencinin öğrendiklerinin kalııılığını sağlamak, öğretmenin ders işlemesini daha kolay ve eğlenceli hale getirmek, öğrencinin sıkılmadan derse etkin olarak katılmasını sağlamak vb. pek çok işlevi olan materyallerin taşıması gereken temel özellikler bulunmaktadır. Yapılan araştırmada, öğretmen adaylarının ÖTMT dersinde hazırlanan öğretim materyallerinin taşıması gereken özellikler arasında en fazla öğrenci seviyesine uygun olması, kullanışı olması, amaca uygun olması, kalıcı öğrenmeyi sağlaması, dikkat çekici olması, açık ve anlaşıır olması, ekonomik olması gerektiğine vurgu yaptığı görülmektedir. Benzer şekilde, Demiralp (2007) araştırmasında öğretimde kullanılan materyallerinin içerdikleri bilginin güncel ve doğru olması, öğrenciyi güdüleyici ve ilgi çekici olması, öğrenciyi derse etkin olarak katabilmesi, teknik özelliklerinin yeterli olması, tarafsız ve 
sadece öğretimsel özellikler taşıması, kullanılan materyale göre anlatım özelliklerinin öğrenci seviyesine uygun olması gerektiğini belirtmektedir. Tulving (1967) ise materyallerin mümkün olduğu kadar doğru, sade, yeni, dayanıklı, ekonomik, kullanışlı ve nitelikli olması, yapı özelliklerinin sağlam olması ve kolayca yıpranmayacak malzemelerden yapılması gerektiğini ifade etmektedir. Kıycan (2009) tarafından yapılan tez çalışmasının bulguları incelendiğinde ise mevcut çalışmayla paralel olarak öğretim materyallerinin dayanıklı olması, konuya ve öğrenci seviyesine uygun olması gerektiği sonucuna ulaşıldığı görülmektedir.

Öğretmen adaylarının görüşlerinden elde edilen bir diğer sonuç, ÖTMT dersinde öğretim materyalinin planlama, uygulama ve değerlendirme aşamalarında dikkat edilmesi gereken özelliklere ilişkin sonuçtur. Öğretim materyalini planlama aşamasında; öğretmen adaylarının tamamının materyalin hedefe uygun olmasına dikkat edilmesi gerektiğini ifade ettikleri, daha sonra sırasıyla öğrenci seviyesine uygun olmasına, konuya ve derse uygun olmasına ve kullanışlı olmasına dikkat edilmesi gerektiğine vurgu yaptıkları görülmektedir. Öğretim materyalinin uygulama aşamasında; öğretmen adaylarının materyalin iyi tanıtılması, öğrenci tarafından kullanılabilmesi ve öğrencinin dikkatinin sağlaması gerektiğine ilişkin görüşlerinin öne çıtığı tespit edilmiştir. Öğretim materyalinin değerlendirme aşamasında ise öğretmen adaylarının hedefe ulaşılıp ulaşıımadığını değerlendirmesine ve objektif değerlendirme yapılmasını sağlamasına dikkat edilmesi gerektiğine ilişkin görüşlerinin öne çıktığı belirlenmiştir. Alım (2015) tarafından yapılan araştırmada da ÖTMT dersini alan öğrencilerin planladıkları materyalin ilgili dersin kazanımlarılya uyuşup uyuşmadığını ve bilişsel alana uygunluğunu belirleyebilmesi gerektiği ifade edilmektedir. Bu nedenle; öğretmen adaylarının bu becerileri etkin olarak kullanabilmeleri için gerekli olan eğitimi ÖTMT dersinde almalarının önemi vurgulanmaktadır.

Öğretim materyali hazırlamanın öğretmen adaylarına sağladığı katkılara ilişkin görüşler incelendiğinde ise bilişsel alana yönelik katkılarının üst düzey düşünme becerilerini geliştirecek materyaller hazırlamayı öğrenme, bilgiyi daha iyi kavratmayı sağlayacak materyalleri hazırlamayı öğrenme, birden fazla duyu organını kullanıımasını sağlayacak materyaller hazırlamayı öğrenme, kalıcı öğrenmeyi sağlayan materyaller hazırlamayı öğrenme; duyuşsal alana yönelik katkılarının materyal hazırlamaya yönelik dikkatini ve ilgisini çekme, materyal hazırlamaya ilişkin olumlu tutum kazanmasını destekleme, materyal hazırlamaya ilişkin özgüven duygusunun gelişimini sağlama; devinişsel alana yönelik katkılarının psikomotor becerilerini geliştirme, kas gelişimini destekleme, materyali doğru ve etkili kullanma becerisini geliştirme; sosyal alana yönelik katkılarının ise sosyalleşmeyi sağlama, işbirlikli çalışmayı öğrenmeyi sağlama, iletişim becerisini geliştirmeyi sağlama olarak öne çıktığı belirlenmiş̧ir. Saka ve Saka (2005) tarafından yapılan araştırma sonuçlarında da öğretmen adaylarının aldıkları ÖTMT dersinin mesleki becerilerinin gelişimini olumlu etkilediği tespit edilmiştir. Kıycan (2009) tarafından yürütülen tez çalışmasında materyal dersinin öğrencilerin sosyalleşmesini desteklediği sonucu ile Yelken (2009)'un araştırmasında yer alan ÖTMT dersinin öğrencilerin yaratıcı düşünme, işbirlikli çalışma becerilerini olumlu etkilediği sonuçları mevcut araştırma sonuçlarını desteklemektedir. Benzer şekilde; Geçer (2010) tarafından yürütülen araştırmada ÖTMT dersinin bilişsel alanda öğrencilere materyal hazırlamayı ve sunmayı, duyuşsal alanda özgüven gelişimini, sosyal alanda iletişim becerisinin ve sosyalleşmenin gelişmesini desteklediği sonuçları mevcut araştırma sonuçları ile paralellik göstermektedir. Acer (2011) araştırmasında öğretmen adaylarının ÖTMT dersinde elde ettikleri kazanımlara yönelik olarak öncelikle öğretmen adaylarının bu dersin yaratıcı ürünler tasarlayabilmelerini sağladığını ifade etmiştir. Ayrıca bu dersin yaratıcı düşünmelerini, özgüvenlerini geliştirdiği, çevredeki objelere daha farklı bakmalarını, çok az malzemeyle materyal tasarlayabilmelerini sağladığı tespit edilmiştir. Sevim (2014)'ün öğretmen adayları üzerinde yaptığı araştırma sonuçları incelendiğinde, ÖTMT dersinin üstbilişsel düşünme becerilerinin gelişimini, özgün ve ilgi çekici materyaller hazırlamalarını desteklediği sonucuna ulaşılmıştır. Bu çerçevede, ÖTMT dersinin öğrencilerin bilimsel becerileri etkin olarak kullanmalarına imkân vererek öğrendiklerini daha iyi aktarabilmelerini, materyalleri gerçek öğrenme ortamlarına daha uygun nitelikte hazırlayabilmelerini sağladığı tespit edilmiştir. Varank ve Akgül (2013)'ün öğretmenlere yönelik 
yaptıkları araştırmada da ÖTMT dersinin özgüvenlerinin gelişimini desteklediği sonucuna ulaşılmıştır. Alım (2015) tarafından yürütülen çalışmada ise ÖTMT dersinin coğrafya öğretmenliği bölümünde okuyan öğrencilere bilişsel alanda öğretim teknolojileri ve materyalleri ile ilgili kavramları, öğretim materyallerinin hangi amaçlarla kullanıldığını öğretmesi; duyuşsal alanda öğretim araç-gereç ve materyallerini kullanma isteği, öğretim materyalleri tasarlayıp hazırlama isteği oluşturması; psikomotor alanda öğretim ortamlarında kullanılan araç-gereç ve materyalleri kullanabilmeyi, doğal ve yapay ortamdan toplanan malzemeleri öğretim amaçlı materyaller üretmek için kullanabilmeyi sağlaması açısından katkı sağladığını belirtmesi araştırma sonuçlarıyla paralellik göstermektedir.

Öğretmen adaylarının ÖTMT dersinin öğretim materyalini hazırlama, uygulama ve değerlendirme boyutlarında yaşanan problemlere ilişkin görüşleri incelendiğinde ise öğretim materyalinin hazırlama boyutunda amacına uygun hazırlayamama, maliyetli olması, öğrenci seviyesine uygun hazırlayamama, zaman alması, malzeme bulmakta sıkıntı yaşama; uygulama boyutunda kullanışı olmaması, öğrencinin dikkatini çekmemesi, materyal kullanma konusunda bilgi eksikliği, sınıfların kalabalık olması, materyal uygulamanın uzun zaman alması, sınıfın fiziki şartlarının yetersizliği; değerlendirme boyutunda ise objektif değerlendirmeyi sağlayamama, sınıf seviyesine uygun değerlendirme yapamama problemlerinin öne çıktığı görülmüştür. Benzer şekilde; Semerci (2006) tarafından öğretmenlerin materyal kullanımı üzerine yürütülen tez çalışmasında, materyal kullanımını olumsuz etkileyen etmenler arasında sınıfların kalabalık olması, materyal hazırlama konusunda yetersiz olunması ifade edilmiştir. Çekirdekçi ve Toptaş (2011) tarafından yapılan araştırmada ise materyal kullanımı sürecinde karşılaşılan sorunların sınıfların kalabalık olması, sınıfların fiziki şartlarının yetersiz olması, sınıf kontrolünün sağlanamaması, materyal uygulamanın çok fazla zaman alması şeklinde sıralandığı ve elde edilen sonuçların mevcut araştırma sonuçları ile paralellik gösterdiği belirlenmiştir. Varank ve Akgül (2013) tarafından öğretmenlerle yürütülen araştırmada da sınıfların kalabalık olması materyal kullanımını olumsuz etkileyen sorunlar arasında ifade edilmiştir.

Elde dilen bir diğer sonuç, öğretim materyali planlayan, uygulayan ve değerlendiren bir öğretmen adayının sahip olması gereken özelliklerin neler olduğuna ilişkin sonuçtur. Öğretim materyalini planlayan bir öğretmen adayının materyal hazırlanacak konu hakkında bilgi sahibi olması, öğrenci seviyesini bilmesi, yaratıcı düşünme becerisine sahip olması, öğretim materyali konusunda bilgi sahibi olması; öğretim materyalini uygulayan bir öğretmen adayının materyali uygun şekilde kullanabilmesi, öğrencinin aktif katıımını sağlaması, güvenlik önlemi alabilmesi, mevcut şartları uygulamaya uygun hale getirmesi, materyali tanıtırken güzel ve açık bir dil kullanması; öğretim materyalini değerlendiren bir öğretmen adayının objektif olması, materyalin amaca hizmet edip etmediği değerlendirebilmesi, dönüt ve düzeltme vermesi gerektiği görüşlerinin öne çıtığı tespit edilmiştir. Devecioğlu, Akdeniz ve Ayvacı (2005) öğretmen adaylarının bu nitelikleri kazanabilmesinde, ÖTMT dersinin oldukça önemli bir faktör olduğunu ve bu dersi alan öğretmen adaylarının özgün materyaller tasarlama, sınıf ortamında uygun olarak kullanma becerilerine sahip olduklarını belirtmektedir. Ayrıca bu derste öğretmen adaylarının materyalleri planlayarak hazırlama, farklı araç-gereçleri ve materyalleri seçebilme, amaca uygun kullanma ve elde edilen sonuçları objektif olarak değerlendirebilme becerilerini kazandıkları belirlenmiştir.

Lisans eğitiminde alınan ÖTMT dersinin öğretmen adaylarının eğitim ortamına yönelik düşüncelerini nasıl etkilediğine ilişkin sonuçlara bakıldığında; olumlu ve olumsuz etkilediğine ilişkin görüşler tespit edilmiştir. Olumlu görüş içerisinde olan öğretmen adayları materyal hazırlamayı, materyalin öğrenmeyi kolaylaştırdığını, öğretim ortamını zenginleştirdiğini öğrendikleri için ve bilginin kalıcılığı konusunda materyalin büyük bir öneme sahip olduğunu fark etmelerini sağladığı için olumlu görüşe sahip oldukları tespit edilmiştir. Olumsuz etkilediğini ifade eden öğretmen adaylarının ise hocanın derse düzenli gelmemesi bu nedenle dersin verimli geçmemesi dersin işlenmesinin ve içeriğinin yetersiz olması, dersin teori ile sınırlı kalması gibi nedenlerden dolayı olumsuz görüş içerisinde oldukları tespit edilmiştir. Elde edilen sonucu 
destekler nitelikte, Yaman (2007) tarafından yürütülen araştırmada da öğretmen adayları kendilerini materyal hazırlama konusunda yetersiz olarak görmekte ve üniversitelerde ÖTMT dersine yeteri kadar önem verilmediğini belirtmektedir. Alım (2007) tarafından öğretmen adaylarının ÖTMT dersine ilişkin görüşlerini belirlemek için yapılan çalışmada, öğretmen adaylarına ÖTMT dersinin teorik olarak öğretildiği ancak materyal kullanımına yönelik uygulamaların yetersiz olarak verildiği sonucuna ulaşılmıştır. Elde edilen sonuç bu çalışmanın sonuçlarıyla uyumluluk göstermektedir.

Son olarak, öğretmen adaylarının okullarda öğretim materyallerinin kullanımına ilişkin görüşlerine bakıldığında; öğretmen adaylarının tamamının materyallerin kullanılması gerektiğini düşündükleri belirlenmiştir. Öğretmen adaylarının önemli bir kısmı okullarda materyal kullanılması gerektiğine ilişkin düşüncelerinin gerekçelerini bilginin kalıcılığını sağlaması, konuyu daha anlaşıır hale getirmesi, öğrenmeyi kolaylaştırması olarak ifade ederken; bazı öğretmen adayları ise okullarda materyalin kullanılması gerektiği ancak okullarda materyal kullanımının öğretmenlerimizin materyal hazırlamasını ve etkili kullanmasını bilmemesi, materyallerin her konu ve ders için kullanılamaması, okulların fiziki imkânlarının yetersiz olması nedenlerinden dolayı yetersiz olduğunu belirtmiştir. Karamustafaoğlu (2006) ise araştırmasında, öğretmen adaylarının materyal kullanımı konusunda yeterli bilgiye sahip olmadıklarını tespit etmiştir. Benzer şekilde, Semerci (2006)'nın araştırmasında; okullarda materyal kullanımının öğrencilerin kalıcı öğrenmelerini olumlu etkilediği ancak okullardaki materyal yetersizliği, öğretmenlerin materyal kullanmayı bilmemesi gibi nedenlerle bunun istenilen düzeyde olmadığını belirtmesi mevcut araştırma sonucunu desteklemektedir. Kurtdede Fidan (2008)'in öğretmenlerle yürüttüğü araştırmanın sonuçlarında da; öğretmenlerin okullarda materyal kullanımının öğrenmeyi somutlaştırdığı, kolaylaştırarak kalıcı hale getirdiği, ancak okullarda yeterli materyalin bulunmadığı yönündeki görüşleri mevcut araştırma sonucu ile örtüşmektedir. Kıycan (2009) tarafından yapılan çalışmada materyal kullanımının kalıcı öğrenmeyi, öğrencinin aktif olarak derse katıımını sağladığı sonucuna ulaşılmıştır. Çekirdekçi ve Toptaş (2011) tarafından yürütülen araştırmada da okulların fiziki olarak yetersiz olmasının materyal kullanımını olumsuz etkilediği tespit edilmiştir. Alım (2012)'in araştırma sonuçları incelendiğinde; okullarda materyal kullanımının öğrenmede kalıcılığı olumlu etkilediği, ancak çoğu okulda klasik sayılabilecek çok basit materyallerin bile olmadığı tespit edilmiş̧ir. Ayrıca Kablan, Topan ve Erkan (2013) materyal kullanımı konusunda yaptıkları meta-analiz çalışmasında elde edilen okullarda materyal kullanımının akademik başarıyı arttırdığı sonucu, okullarda materyallerin kullanılması gerektiği sonucunu desteklemektedir. Bunun yanı sıra bazı öğretmenlerin materyal kullanımı konusunda bilgi eksikliğinin olması sebebiyle isteksiz olabileceği ifade edilmektedir. Bu durum, lisans eğitimde ÖTMT dersinin verimli, düzenli verilmesi ile aşılabilecek bir problemdir. Savran (2004)'ün Türkçe öğretmenleri üzerine yaptığı tez çalışmasında elde ettiği sonuçlara göre öğretmenlerin \% 71'nin bu konuyla ilgili kurs ihtiyacının bulunduğu belirlenmiştir. Elde edilen sonuca göre de aktif görev yapan öğretmenlerin materyal hazırlama ve kullanma konusunda hizmetiçi eğitim, kurs, seminer vb. etkinliklerle bilgilendirilmesi gerekmektedir.

\section{ÖNERILER}

- Üniversitelerde ÖTMT dersinin daha etkili ve işlevsel olarak verilmesi için ÖTMT ders içerikleri ve işleyişi tekrar gözden geçirilmelidir. Böylece öğretmen adaylarının materyal planlama, hazırlama, uygulama, değerlendirme konusunda daha donanımlı yetişmeleri sağlanmalıdır.

- Üniversitelerde ÖTMT dersini alan öğretmen adaylarının hazırladıkları materyalleri kullanabilmeleri için okullarla işbirliği yapılmalıdır. Bu sayede öğretmen adayının hazırladığı materyalin eksik ve uygun olmayan yönlerini fark etmesi sağlanmalıdır.

- Okullardaki materyal eksikliğinin giderilmesine yönelik Milli Eğitim Bakanlığı́nın desteği alınmalıdır. Ayrıca okullarda olan ancak işlevsel olmayan materyaller de tekrar gözden geçirilerek güncellenmelidir. 
- Okullarda var olan materyallerin korunabilmesi için okul imkânları ölçüsünde belirli alanların oluşturulması sağlanmalıdır.

- Aktif görev yapan öğretmenlerin materyal kullanımı ve öğrenme ortamına katkıları konusunda bilgilendirilmesi için hizmet içi eğitim, kurs, seminer vb. düzenlenmeli ve öğretmenlerin katılımı sağlanmalıdır.

\section{KAYNAKÇA}

Acer, D. (2011). Okulöncesi öğretmen adaylarının materyal geliştirme dersine ilişkin görüşlerinin incelenmesi. Illköğretim Online, 10(2), 421-429.

Alım, M. ve Girgin, M. (2004). Öğretmen ve öğrenci görüşlerine göre 9. sınıf coğrafya derslerinde yararlanılan araç-gereçler ile materyal ve öğretim yöntemleri. Doğu Coğrafya Dergisi, 9(12), 25-42.

Alım, M. (2007). Öğretim teknolojileri ve materyal geliştirme (ÖTMG) dersinin önemi ve öğretim sürecine ilişkin öneriler/The ıportance of teaching technologies and material development course and suggestion on the teaching process. Doğu Coğrafya Dergisi, 12(17), 243-262.

Alım, M. (2012). Coğrafya dersleri için materyal tasarımı. Eastern Geographical Review, 17(27), 73-84.

Alım, M. (2015). Coğrafya öğretmeni adaylarının öğretim teknolojileri ve materyal tasarımı. Doğu Coğrafya Dergisi, 20(33), 1-10.

Alkan, C. (1979). Eğitim ortamları. Ankara: Ankara Üniversitesi Eğitim Fakültesi Yayınları.

Allwright, R. L. (1981). What do we want teaching materials for? 1. ELT journal, 36(1), 5-18. DOI: https://doi.org/10.1093/elt/36.1.5.

Avcıoğlu, H. (2012). Zihin engelliler sınıf öğretmenlerinin araç-gereç kullanımına ilişkin görüşleri. International Journal of New Trends in Arts, Sports \& Science Education, 1(2), 118-133).

Binbaşıŏlu, C. (1988). Genel öğretim bilgisi. Ankara: Binbaşıoğlu Yayınları.

Birişçi, S. ve Karal, H. (2011). Öğretmen adaylarının bilgisayar destekli ortamda materyal tasarlarken işbirlikli çalışmalarının yaratıcı düşünme becerilerine etkisi. Journal of Kirsehir Education Faculty, 12(2), 203219.

Borich, G. D. (2014). Etkili öğretim yöntemleri. Bahattin Acat (Çev.) Ankara: Nobel Yayıncılık.

Büyükkaragöz, S. (1996). Genel öğretim metotları. İstanbul: Özeğitim Yayınları.

Büyüköztürk, Ş. (2010). Sosyal bilimler için veri analizi el kitabı. (11. Baskı). Ankara: PegemA Yayıncılık.

Büyüköztürk, Ş., Kılıç Çakmak, E., Akgün, Ö. A., Karadeniz, Ş. \& Demirel, F. (2014). Bilimsel araştırma yöntemleri. (17. Baskı). Ankara: PegemA Yayıncılık.

Creswell, J. W. (2016). Nitel araştırma yöntemleri. Beş yaklaşıma göre nitel araştırma ve araştırma deseni. M. Bütün ve S. B. Demir (Çev.). (3. Baskı). Ankara: Siyasal Kitabevi.

Çekirdekçi, S. ve Toptaş, V. (2011). Sınıf öğretmenlerinin matematik (4. ve 5.sınıf) dersinde öğretim materyalleri kullanımını engelleyen unsurlarla ilgili görüşleri. Pamukkale Üniversitesi Eğitim Fakültesi Dergisi, 29(1), 137-149.

Çelik, Y. (2009). Özel okullarda ve devlet okullarında görev yapan fen ve teknoloji dersi öğretmenlerinin eğitim araç gereçlerinden yararlanma durumlarının incelenmesi. (Yayınlanmamış Yüksek Lisans Tezi). Yüzüncü Yı Üniversitesi Fen Bilimleri Enstitüsü, Van.

Demiralp, N. (2007). Coğrafya eğitiminde materyaller ve 2005 coğrafya dersi öğretim programı. Kastamonu Eğitim Dergisi, 15(1), 373-384.

Demirel, Ö. (2011). Öğretme sanatı. Öğretim ilke ve yöntemleri. (17. Baskı). Ankara: PegemA Yayıncılık.

Devecioğlu, Y., Akdeniz, A. R. ve Ayvacı, H. (2005). Okul öncesi öğretmen adaylarına fen öğretiminde rehber materyal geliştirme becerileri kazandırmak için bir yaklaşım. Buca Eğitim Fakültesi Dergisi, 18, 64-72.

Ellis, R. (1997). The empirical evaluation of language teaching materials. ELT journal, 51(1), 36-42. DOI: https://doi.org/10.1093/elt/51.1.36

Fidan, N. K. (2008). illköğretimde araç gereç kullanımına ilişkin öğretmen görüşleri. Kuramsal Eğitimbilim, $1(1), 48-61$.

Geçer, A. K. (2010). Teknik öğretmen adaylarının öğretim teknolojisi ve materyal geliştirme dersine yönelik deneyimleri. Yüzüncü Yıl Üniversitesi Eğitim Fakültesi Dergisi, 7(2), 1-25.

Glaser, B. ve Strauss, A. L. (1967) Discovery of grounded theory: Strategies for qualitative research. Chicago: Aidine.

Gündüz, Ş. ve Odabaşı, F. (2004). Bilgi çağında öğretmen adaylarının eğitiminde öğretim teknolojileri ve materyal geliştirme dersinin önemi. The Turkish Online Journal of Educational Technology, 3(1), 4348. 
Güven, S. (2006). Öğretim teknolojileri ve materyal geliştirme dersinin kazandırdığı yeterlikler yönünden değerlendirilmesi (İnönü Üniversitesi Eğitim Fakültesi örneği). Türk Eğitim Bilimleri Dergisi, 4(2), 165179.

Kablan, Z., Topan, B. ve Erkan, B. (2013). Sınıf içi öğretimde materyal kullanımının etkililik düzeyi: Bir metaanaliz çalışması. Kuram ve Uygulamada Eğitim Bilimleri, 13(3), 1629-1644. DOI: 10.12738/estp.2013.3.1692

Kaptan, S. (1973). Bilimsel araştırma teknikleri. Ankara: Rehber Yayınevi.

Karamustafaoğlu, O. (2006). Fen ve teknoloji öğretmenlerinin öğretim materyallerini kullanma düzeyleri: Amasya ili örneği. Bayburt Eğitim Fakültesi Dergisi, 1(1), 90- 101.

Kıycan, S. (2009). İlköğretim 4. ve 5. sınıflarda sosyal bilgiler dersinde (araç-gereç) materyal kullanımının öğrenci başarısına etkisi (Kars ili örneği). (Yayınlanmamış Yüksek Lisans Tezi). Kafkas Üniversitesi Sosyal Bilimler Enstitüsü, Kars.

Köseoğlu, P. ve Soran, H. (2006). Biyoloji öğretmenlerinin araç-gereç kullanımına yönelik tutumları. Hacettepe Üniversitesi Eğitim Fakültesi Dergisi, 30, 159-165.

Kurtdede Fidan, N. (2008). İlköğretimde araç gereç kullanımına ilişkin öğretmen görüşleri. Kuramsal Eğitimbilim, 1(1), 48-61.

Küçükahmet, L. (2000). Öğretimde planlama ve değerlendirme. (11. Baskı). Ankara: Nobel Yayıncılık.

McLoughlin, C. (1999). The implications of the research literature on learning styles for the design of instructional material. Australian Journal of Educational Technology, 15(3), 222-241. DOI: https://doi.org/10.14742/ajet.1859

Nalçacı, A. ve Ercoşkun, M. H. (2005). İlköğretim sosyal bilgiler derslerinde kullanılan materyaller. Atatürk Üniversitesi Kazım Karabekir Eğitim Fakültesi Dergisi, 11, 353-370.

Patton, M. Q. (2014). Nitel araştırma ve değerlendirme yöntemleri. M. Bütün ve S. B. Demir (Çev.). (1. Baskı). Ankara: PegemA Yayıncılık.

Paykoç, F. (1991). Tarih öğretimi. Eskişehir: Anadolu Üniversitesi Açık Öğretim Fakültesi Yayınları.

Sağlam, H. İ. (2010). Sosyal bilgiler dersinde öğretim materyalleri ölçeği çalışması. Sakarya Üniversitesi Eğitim Fakültesi Dergisi, 19, 89-99.

Saka, A. Z. ve Saka, A. (2005). Öğretmen adaylarının öğretim teknolojileri ve materyal geliştirme dersinde mesleki becerilerini geliştirme düzeyi. Sakarya Üniversitesi Eğitim Fakültesi Dergisi, 10, 81-89.

Savran, A. (2004). İlköğretim okullarının ikinci kademesindeki Türkçe öğretmenlerinin eğitimde araç gereç kullanımına ilişkin görüşleri. (Yayınlanmamış Yüksek Lisans Tezi). Marmara Üniversitesi Eğitim Bilimleri Enstitüsü, İstanbul.

Semerci, A. (2006). İlköğretim birinci kademede görev yapan sınıf öğretmenlerinin, etkili materyal kullanma yeterlilikleri üzerine öğretmen ve yönetici görüşleri (Antalya örneği). (Yayınlanmamış Yüksek Lisans Tezi). Fırat Üniversitesi Sosyal Bilimler Enstitüsü, Elazığ.

Senemoğlu, N. (2007). Gelişim, öğrenme ve öğretim. Ankara: Gönül Yayıncılık.

Sevim, O. (2014). Disiplinlerarası materyal geliştirme sürecinin Türkçe öğretmen adaylarının öğretim tasarımı başarılarına ve üstbilişsel farkındalıklarına etkisi. Turkish Studies-International Periodical for the Languages, Literature and History of Turkish or Turkic, 9(9), 897-913. DOI: 10.7827/TurkishStudies.7084

Sönmez, Ö. F. (2006). İlköğretim sosyal bilgiler 7. sınıf Karadeniz Bölgesi konusunun görsel araç-gereçlerle öğretiminin öğrencilerin akademik başarısına etkisinin değerlendirilmesi (Tokat örneği). (Yayınlanmamış Yüksek Lisans Tezi). Gazi Üniversitesi Eğitim Bilimleri Enstitüsü, Ankara.

Sönmez, V. (2005). Program geliştirmede öğretmen el kitabı. Ankara: Anı Yayıncılık.

Sönmez, V. ve Alacapınar, F. G. (2011). Bilimsel araştırma yöntemleri. (1. Baskı). Ankara: Anı Yayıncılık.

Şahin, T. Y. ve Yıldııım, S. (1999). Öğretim teknolojileri ve materyal geliştirme. Ankara: Anı Yayıncılık.

Şaşmaz Ören, F. ve Ormancı, Ü. (2012). Öğretmen adaylarının çalışma yaprağı geliştirme ve kullanma uygulaması ile bu uygulamaya yönelik görüşlerinin değerlendirilmesi. Kuram ve Uygulamada Eğitim Bilimleri, 12(1), 241-270.

Türk Dil Kurumu (TDK). (2005). Türkçe sözlük. Ankara: TDK.

Tekdal, M. (2004). E-Öğrenimde yeni bir boyut: öğrenme nesneleri. Çukurova Üniversitesi Eğitim Fakültesi Dergisi, 28(2), 7-12.

Toprakçı, E. (2007). The profiles of the use of the internet for study purposes among university students. The Turkish Online Journal of Educational Technology - TOJET, 6(3), 129-144.

Tulving, E. (1967). The effects of presentation and recall of material in free-recall learning 1 . Journal of Verbal Learning and Verbal Behavior, 6, 175-184. DOI: https://doi.org/10.1016/S00225371(67)80092-6 
Varank, İ. ve Akgül, A. (2013). Öğretmenlerin Uygulamaya Dayalı Öğretim Teknolojileri ve Materyal Tasarımı Özyeterlik Algılarının Öğrencilerin Seviye Belirleme Sınavı (SBS) Başarısı Ille İlişkisi. Journal of Social Sciences [JSS], 12(2), 253-265.

Yaman, H. (2007). Türkçe öğretmeni adaylarının" öğretim teknolojileri ve materyal geliştirme" dersi bağlamında Türkçe öğretiminde teknoloji kullanımına ilişkin yeterlilik ve algıları. Hasan Ali Yücel Eğitim Fakültesi Dergisi, 4(1), 57-71.

Yelken, T. Y. (2009). Öğretmen adaylarının portfolyoları üzerinde grup olarak yaratıcılık temelli materyal geliştirmenin etkileri. Eğitim ve Bilim, 34(153), 83-98.

Yenilmez, K. ve Yolcu, B. (2007). Öğretmen davranışlarının yaratıcı düşünme becerilerinin gelişimine katkısı. Sosyal Bilimler Dergisi, 18, 95-105.

Yıldıım, A. (1999). Nitel araştırma yöntemlerinin temel özellikleri ve eğitim araştırmalarındaki yeri ve önemi. Eğitim ve Bilim, 23(112), 7-17.

Yıldııım, A. ve Şimşek, H. (2005). Sosyal bilimlerde nitel araştırma yöntemleri. (5. Baskı). Ankara: Seçkin Yayıncilık.

Yontar, A. (1993). İnsanda yaratıcılığın gelişimi, yaratıcılık ve eğitim, Türk Eğitim Derneği, eğitim dizisi. Ankara: Şafak Matbaacılık. 


\section{Preservice Teachers' Views about the Course Teaching Technologies and Material Design}

\author{
Assoc.Prof. Dr. Ebru Bozpolat \\ Cumhuriyet University- Turkey \\ ebozpolat@gmail.com
}

\author{
Aysel Arslan (Lecturer) \\ Cumhuriyet University - Turkey \\ arslanaysel.58@gmail.com
}

\begin{abstract}
The purpose of this study is to determine preservice teachers' views about the course "Teaching Technologies and Material Design" (TTMD). In this research using the qualitative research method, the case study is used which allows the in-depth study of a case. The research conducted with 50 preservice teachers studying at the Faculty of Education, Cumhuriyet University, during the spring term of the 2016-2017 academic year. In this research used a semi-structured interview form consisting of seven questions as a data collection tool. To this end, preservice student teachers were asked questions concerning characteristics that teaching materials should have, points to be considered when preparing teaching materials, contributions of material preparation, problems encountered in material preparation, characteristics that preservice teachers preparing materials should have, contributions of TTMD course, and the use of teaching materials in schools. In the analysis of data, content analysis method was used. According to the obtained findings, preservice teachers stated that teaching materials should be in accordance with the targets, be appropriate to students' level and usefulness. It is among the other findings that prepared materials facilitate learning, promote the permanence of knowledge and should be used in all schools.
\end{abstract}

Keywords: Teaching technologies, material design, preservice teacher

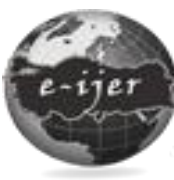

E-International Journal of Educational Research, Vol: 9, No: 3, 2018, pp.60-84

DOI: 10.19160/ijer.463977

\section{Suggested Citation:}

Bozpolat, E. \&. Arslan, A. (2018). Preservice Teachers' Views about the Course Teaching Technologies and Material Design, E-International Journal of Educational Research, Vol: 9, No: 3, 2018, pp. 60-84, DOI: 10.19160/ijer.463977 


\section{EXTENDED ABSTRACT}

Problem: The purpose of this study is to determine preservice teachers' views about the course "Teaching Technologies and Material Design" (TTMD). To this end, preservice student teachers were asked questions concerning characteristics that teaching materials should have, points to be considered when preparing teaching materials, contributions of material preparation, problems encountered in material preparation, characteristics that preservice teachers preparing materials should have, contributions of material design course, and the use of teaching materials in schools.

Method: In this research using the qualitative research method, the case study is used which allows the in-depth study of a case. The study group of research consisted of 50 preservice teachers studying at the Faculty of Education, Cumhuriyet University, during the spring term of the 2016-2017 academic year. The preservice teachers were selected on the basis that they took the TTMD course and volunteered to participate. This study adopted interview method and used a semi-structured interview form consisting of seven questions as a data collection tool. The data were analyzed using content analysis.

Findings: According to the study results, considering the characteristics that teaching materials prepared in the TTMD course should have, the preservice teachers most strongly emphasized that they should be appropriate to students' level, be useful, be suitable for the purpose, provide permanent learning, be remarkable, be clear and understandable, and be economical.

The preservice teachers also held the view that the planning, implementation and evaluation stages should be considered when preparing teaching materials in the TTMD course. Accordingly, for the planning stage of a teaching material, all preservice teachers first emphasized the appropriateness to the target, which was followed by the appropriateness to students' level, the appropriateness to topic and class, and usefulness, respectively.

For the implementation stage, the preservice teachers foregrounded that a teaching material should be well introduced, usable by students and draw students' attention. According to preservice teachers' views about the evaluation stage, whether the target is achieved should be evaluated and an objective evaluation should be ensured.

Considering the contributions of material preparation to preservice teachers, they reported the following views; cognitive contributions include learning to prepare materials that improve highlevel thinking skills, learning to prepare materials that provide better understanding of knowledge, learning to prepare materials that enable the use of multiple sense organs, and learning to prepare materials that facilitate permanent learning. Affective contributions include attracting attention and interest in preparing materials, supporting the acquisition of positive attitude towards material preparation, and fostering the development of self-esteem for material preparation. Psychomotor contributions include promoting the development of psychomotor skills, supporting muscle development, and improving the ability to use materials correctly and effectively. Social contributions include fostering socialization, helping to learn collaborative working, and facilitating the improvement of communication skills.

According to the preservice teachers' views about the problems encountered in the planning, implementation and evaluation stages of material preparation, the problems encountered in the planning stage include the failure to prepare a material for its purpose, its being costly, the failure to make it appropriate to students' level, its taking time, and having difficulty in finding supplies. The problems encountered in the implementation stage include unusefulness, the failure to attract students' attention, the lack of information about using materials, crowded classes, the long time needed for material implementation, and the inadequacy of classrooms' physical conditions. The 
problems encountered in the evaluation stage include the failure to make an objective evaluation, and the failure to make an evaluation appropriate to the class level.

The preservice teachers also reported their views about the characteristics that should be possessed by preservice teachers planning, implementing and evaluating materials. Accordingly, they foregrounded that a preservice teacher planning teaching materials should be informed of the subject related to materials, be aware of students' level, have creative thinking skills, be informed of teaching materials. A preservice teacher implementing teaching materials should use materials properly, ensure students' active participation, take security precautions, make the existing conditions suitable for the application, and use a good and clear language while introducing materials. A preservice teacher evaluating teaching materials should be objective, evaluate whether materials serve their purpose, and provide feedback and correction.

Considering the results of how the undergraduate TTMD course affects preservice teachers' opinions on learning settings, it has positive and negative effects. According to the preservice teachers with positive views, materials are of major importance since they make preservice teachers aware that materials facilitate learning, enrich learning settings, and promote the permanence of knowledge. On the other hand, some preservice teachers took negative views for the following reasons: the class is not efficient because the lecturer does not give the class regularly, the class is not held and its content is inadequate, and the class is limited by theory.

Lastly, considering the preservice teachers' views about the use of teaching materials in schools, all preservice teachers reported that teaching materials should be used in schools. For a significant number of preservice teachers, the reasons for their views on the need to use materials are that teaching materials promote the permanence of knowledge, they make the subject more understandable, and they facilitate learning. Some preservice teachers reported that teaching materials should be used in schools; however the use of teaching materials in schools is inadequate since teachers do not know how to prepare and use materials effectively, teaching materials cannot be used for every subject and class, and schools' physical possibilities are insufficient.

Based on these results, the study offer following suggestions: reviewing the content and delivery of the TTMD course to facilitate a more effective and functional teaching, cooperating with schools so that they can use materials prepared by preservice teachers taking the TTMD course, ensuring support from the Ministry of National Education to eliminate the lack of materials in schools, and organizing in-service training, courses, and seminars to inform in-service teachers about the use of materials and their contributions to learning settings, and accordingly promote their participation. 